急じ指と

な原のて走

措因. 強後族

置を化をな

や究と断 ご

対 明心た少

応卞 5 年

にる加い非

留こたが行

ま亡 ち、、を

るはでそ始

だ必対れめ

け可応らと

でしがのし

な まな 䦎て

く容さ題

易れに最

心でて 対 近

理はい処で

学なるすす

やい。るい

社が青たじ

会、少めめ

学青年にに

精少を通よ

神の年敢常る

医問 巻 教 殺

学 題々育

な が社 相 登

亡゙複 会談校

を雑罟の拒

含化境充否

たあ複・童

総る雑拡の

合い化大増

的はに之加

見深よかな

地刻り、品

少化、教 青

らして育少

れいら場の

らるので問

の 以病 $の$ 題

問上理管は

題、の 理依

の応生や然
へなの示そはそエ

の非理しし諸れリこ

参行論たて価はクの

加現は。今值概ソ論

上象概暴日の将 ン文

逸にね走の调発のは 脱は非太落達自今 少界をどよ理同旦

りの発のなる学二暴 た非達非り価的性㭟 て価上行た值アに越 る值のをがのプ関や 重化危理ら主口导不 要亡機解な観 白良良 な競のすい化手発良 動争現る青、で達生 機社れた少まあ理集 で会とめ年たつ論集 あ状見门のそては岕 る況て同心れに楮に青青 之対る性の伴行年素 を索た危背うを期少 キ 示るめ機景競社の年の 记反威青青世争会韭非 ワた感青青世社病行侨 ド势年期の萮学逸や めの危脱之的脱逸 ら病機価いに行脱 れ理に值う理動動 るのよ化視解を動 の社るに点し理を で会非伴をよ解社 あ学行う青うす会 り的亡競少上る病 、要い争年すた理 そ因う社のるめ学 れを概会病吉の的

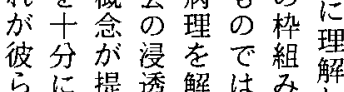
らに提透解はみ解 を解示亡明なと兄 濌明さ心卞少し

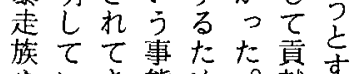
やいき態め。献 不なたがにそしる 良いがあ導こて試 集現ここ忩できな゙

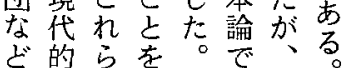

現
社
念
学
研
究
第
巻
九
九
吾
年
六
公
入
夏

治

彦
価

值

の

転

倒

と

少

年

非

行 


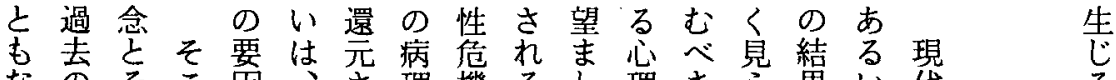

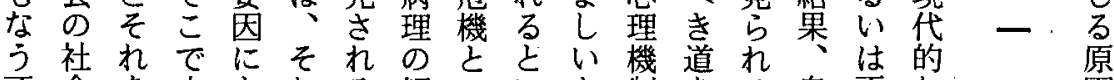
不会を本と执る解いい文制をる自否な 否因

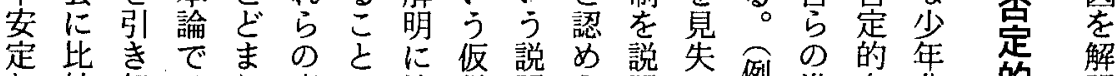
な較起はり病に適説明ら明い例進自非的明

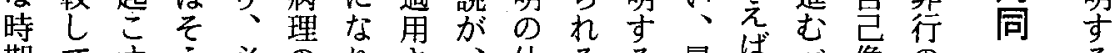
期てすう必のりさす仕るる暴代へ像の- る

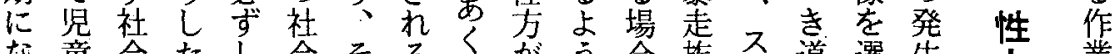
な童会たし会そる段ま青方合族杀道選生主業 てと要少説背しにでる肯青ど!見す序市求 い成因年得景たな発程定年の当失るをの こ期つ病を、題々羊の自の良手、い明会㞦

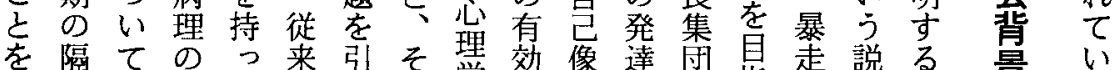
を隔てのっ来引そ理効像達団見走説る景い

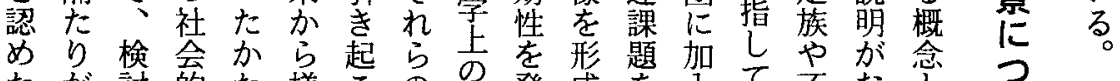
たが討的た様この発成を入て不なと 上拡を背ち令問般揮守う方練良さし で大加景での社題般的るるる習生れて

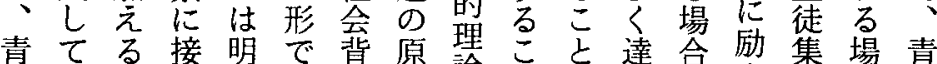
年いこ近示指景因論とに成怘ん団合年 期ると古さ摘のがでは失でこでにが期 のこにる施さ分結あ言敗きれい参しに 行亡したて机析局る言しなにた加ば達 動をためこてがは年たな相高すしし に指い、なきあ当㤂で結つ当校るばた

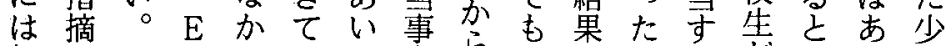

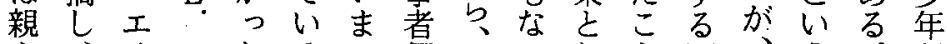
や、リ $\mathrm{H}$ たるい個そいしとし、う。が

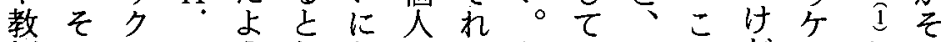
師のソエうしなの代し、うが、青の へ結ンリにてつ資少かそましやス年葛 の果はク思もて䫌年しれりた故が期藤 反、、ソわ、い韭、ら学否障非にの 抗青現ンれある特行青の校定な行あ結 ば年代のるく性や年否や的ど臨り果 か期社否。ま考や暴期定地自の床が

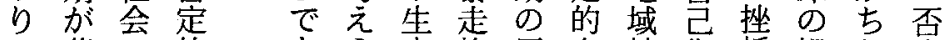
で葛に的もら龍族反自社像折場な定 な藤お同背机環な抗主会がにに挫的 くやい景る境ら゙と像に選よお折同

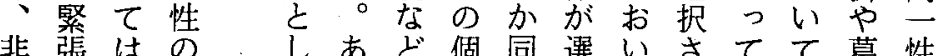

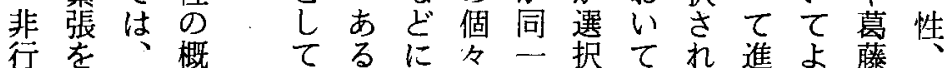




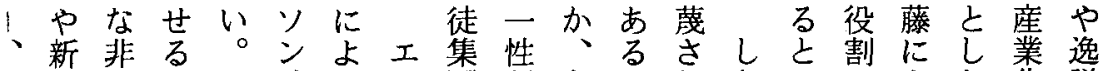
ま田行とそ、るい村がといれかいた化脱 た健をいれ一急クに選いは枯いう到っ社さ行 は二引うゆ九激り加択う、嫝、。達て会れ動 社がき指え五なン人さ疑なわ工住し生化たも 会、起摘、 $○$ 社はすれ問ぜれり祀さむ゙の社含 統まこに社 制たすは会彼变そケ場十般より?と自程にれ の精二確変に動う

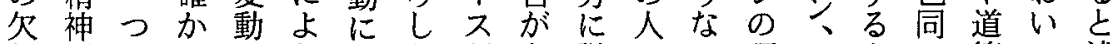
如医のににれ伴たがあ説々 た理—よ二筋て述 に学重娈起ばい同しる明か例論古り性がは心゙

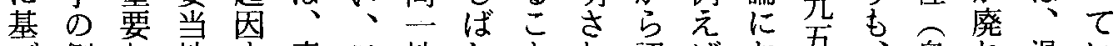

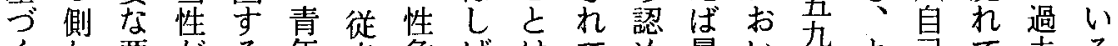

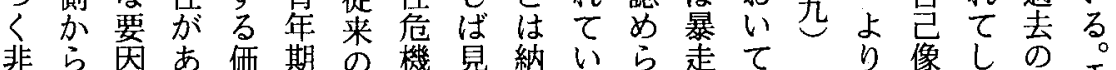

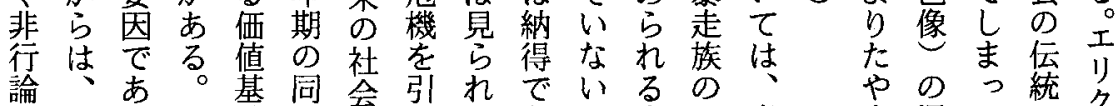

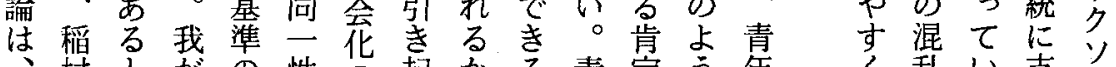

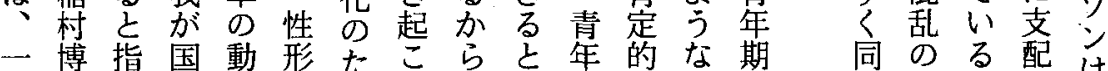

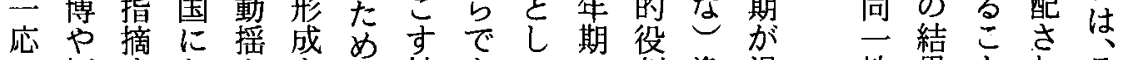
の福寺扰やとの社あての割逸過性果亡れこ 妥島るい混い過会る。毛に脱渡自己をた 当章研て 乱 う程背。指対集的獲し指社し

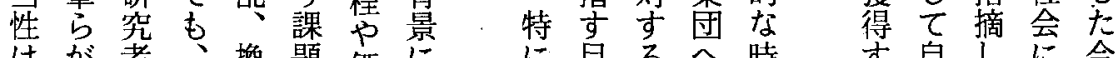
はが者、換題価にに目るへ時市自しに今 あ従は戦言は值决 深標憎の期 る芑て比日 る来多後守何基し 刻にし同で このい較の

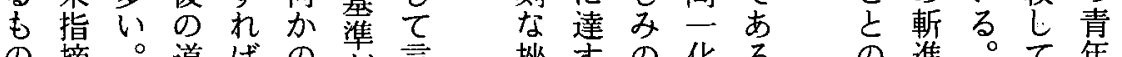
の 摘 ${ }^{2}$ 道

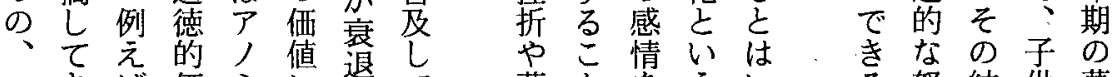

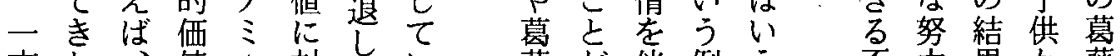

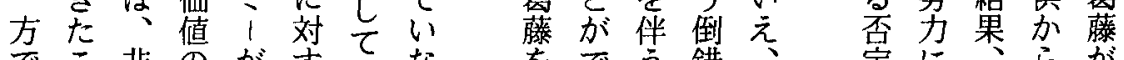

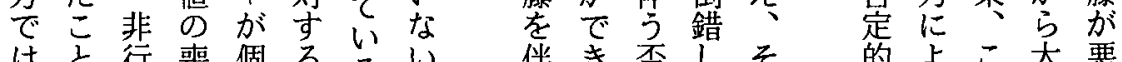

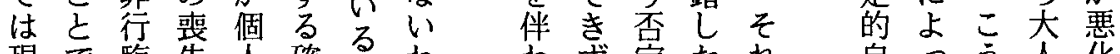

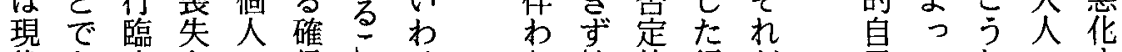
代あ床との信之け な挫的行が芑てしへ卞 がるの心青な在で折同動な像はた る

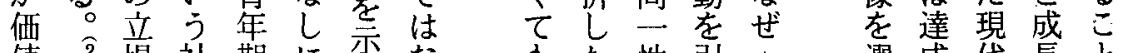

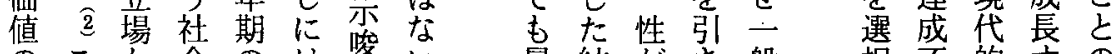

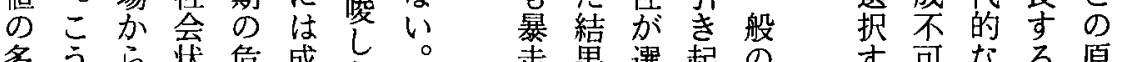
多 らら状危成た。走果選起の打可なる原 様しは況機就た。彼族果択气人起能青た因 化た、がをさっは否さすす々 のア 奥現熏れ工産不定れの加合肯期のし 時, 村代化えり業良的るからら品定の確て 代ミ晋的さなク化生同の、軽 あ的葛固 
た 鬲无含

青簡杂昆

族子紀青厄

の工机少本

逼注哲哲猃

心暑方者社は

に来にF会淍

代口な。病こ

力身了二理 j

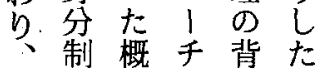

功度愈工景観

利加息に点

梨廃交分策

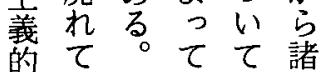

な平示理偳

道均呮解值

徳华さをす

㤎平管淍

垷等さ方

筧化占助

架的けた

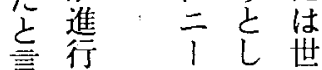

言㜪秋界

近尔諸

花影諸撢

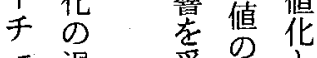

弪過、受调忘

一筑落方

八沶分ま伖

八い.ッた説

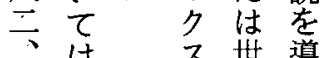

一㓯界

八従站手

八来工非る

六表与覆宅

彼的，化织

にでにとよ

点弯点隹员

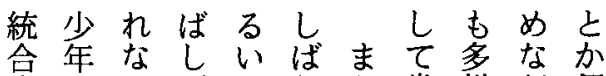
哥の代はな。常様が個

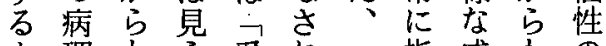

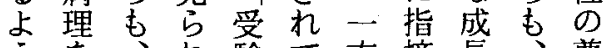

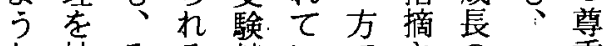
な社そる競いでさの工重

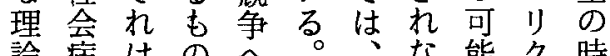
論病はの人。な能少時 理必での例現が性り代

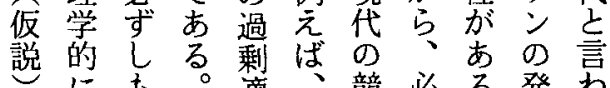

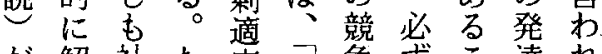
が解社态悹今争或气達机

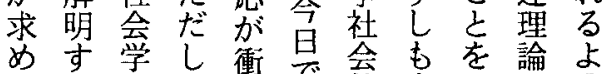

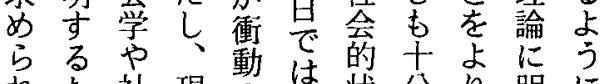

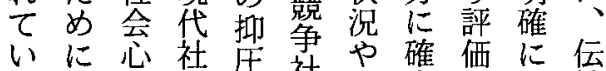

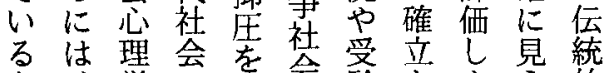

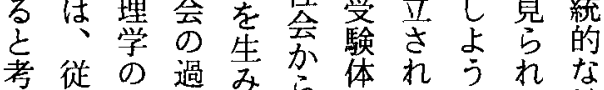

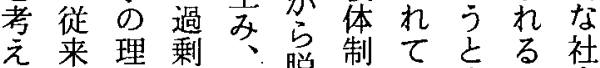

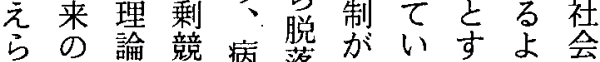

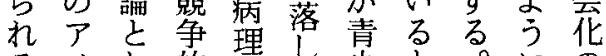

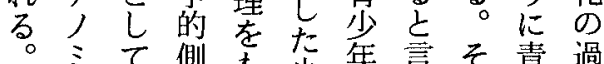

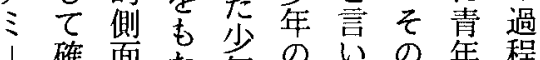
磼面た省のいの年程 諭妾㤎等病難た期加 的を守叒理心 の廃 視机非点点老上自机 点て行㤎引广律た 等な福奜きに, 性結

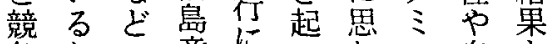

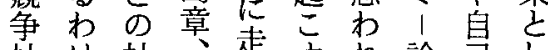

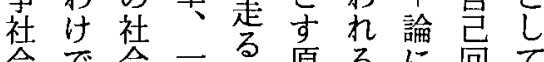
会で会一学原る统回て 台は病九界。基復青 病な理八新で能年 理いの一思古势期 老。一向健方非を更

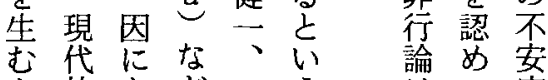

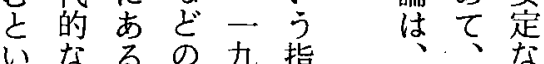

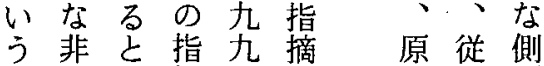
視行指摘こ毛因来面 䖒や摘はしし論よを 荽青さしあば暨り認 


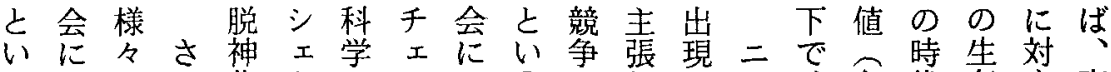
うおのて化 1 の のつうのしに 競近今発口い三体たょ千か数に劣貴

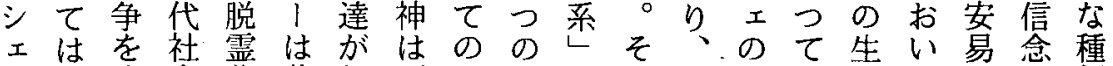
门生会化共伝死見人がう従影のをてにや類 ラそじは以通統ん方間出し来響至容はす誇の 1うて伝あし的だに類現たの暑高易方るり人 がしい統るてなしは型し近子受のに高類を間 近たる。的るい制上多がた代高け価标次の持と

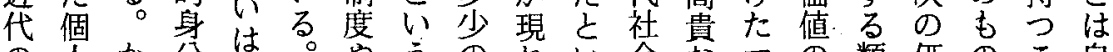
の人汃分巣こ占うの㣗い会な、の類価のこ自

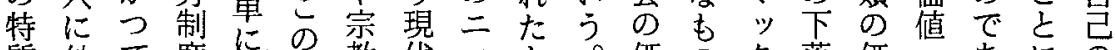

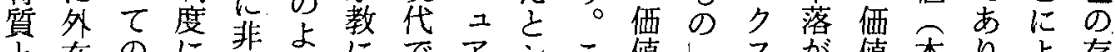
と在のに非うにでアシこ值しス唯値本り去存

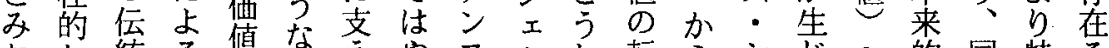
なな統る化旧えやス、し軽らシ心゙へ的同特そ す価社拘亡来らやの ラた倒

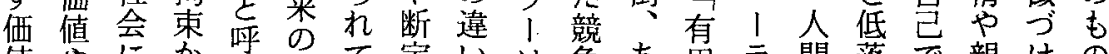
値やにかん諸て定いは争あ用亏間落で親けの の諸おらそ語い的が言社るないの要あ切らを 主制い解よ䡩たに認方会心もは卑るるる犯肯 観度て放い侮価見め。会はの、小傾と忍る定 化がはさざ调值えらき出止今华向い耐亡し

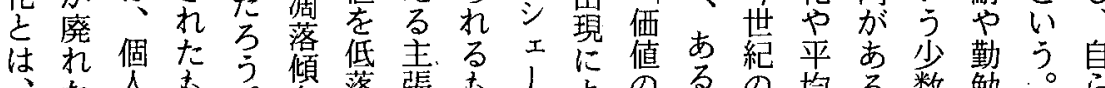

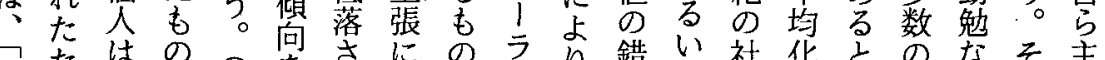

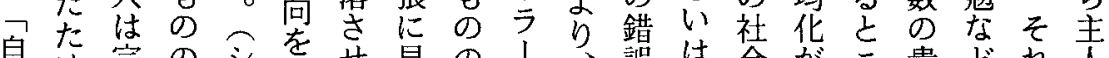

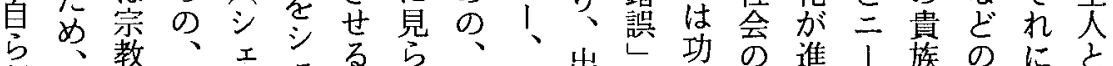

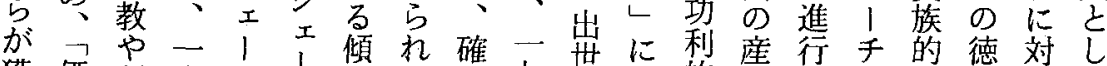

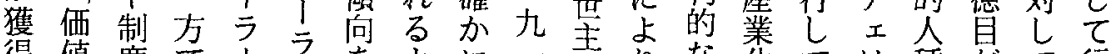
得值度で、フををに二義りな化ては種がて行 しのには、の認う共九者、もにい洞に賞功動 た主よ地一定識に通こ自成のよる察基賛利寺

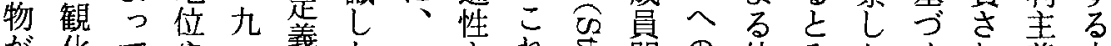
が化てや二我た二立㤂間の仕みたく机義人 価定財五做と九連ら怘の価事な。气る 的間 值之位な做と世続云导儿值本し二こ。道の

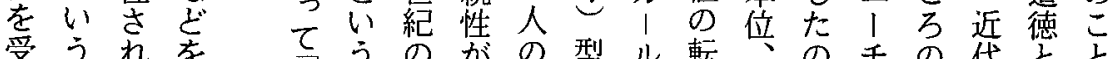

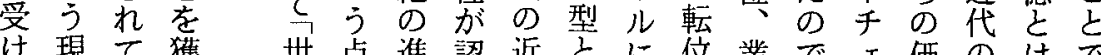
る象い得界点進認近々代儿基方業で績あは価平はで

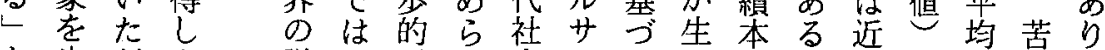
と生がよ脱三思机会ンく无位。代が化兴、

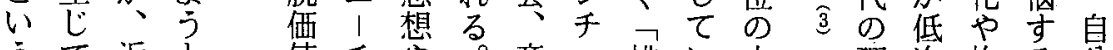

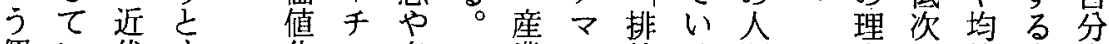
個い代要化工自二業之他る間念の等人自 人る社る と然社型的との高価化間身 
を值しはを感にならとのがれへるこっい主

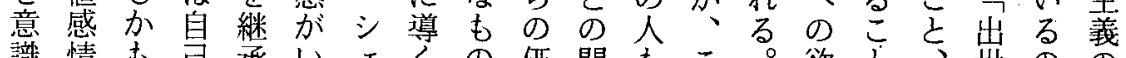
識情も芑承い土穴の価間毛こ。欲亡!世のの しは自のしか!価は值に財のこ求によ主で原 て、己能てにラ値どを葛産場のを意り義あ理 形自の为影化求藤や合夕持味価者るで 成他本や凉響のそもぬが地はイたを值し。あ

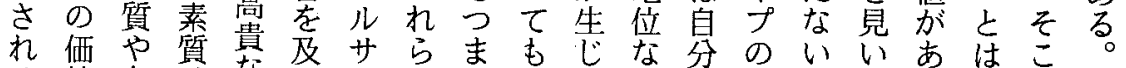

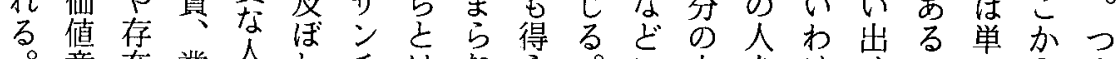
意在業人し子はなら。に力をけせるにらま そ識そ績之・てマ正い机そ魅でシでずと地近り れののなといン反もなるせは和を位代徒 ゆ比もど号る論対のいでら達」な自自やに来 え較のに穃かはのだと彼れ成うい占㞯財特の

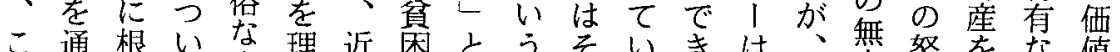

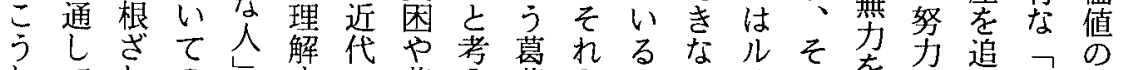

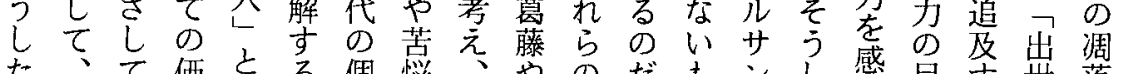
た、て価之る個悩、やのだもンし感目李世落

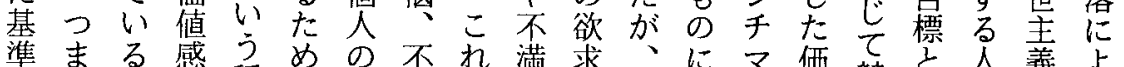
準まる感種めの不れ満求、にマ価競々義よ にりよ情種に価幸らかをそ対ン値競すを者る 従ようか類重値やのら心れす型へ争る指型世 えりならの要形死価は理をるとのによ考市 ば高自構分无成の值彼学達反心欲参うの上の

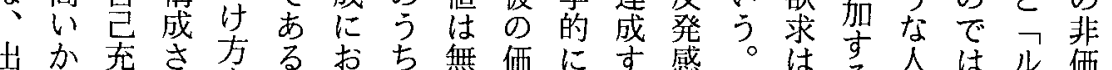
世低実扎を。いに意値言るやル求る合な专值

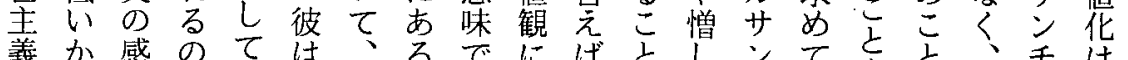

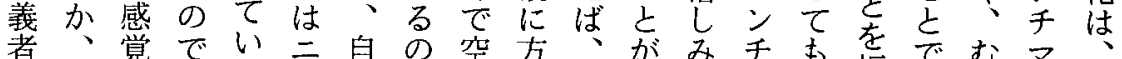

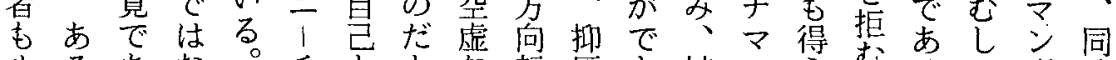

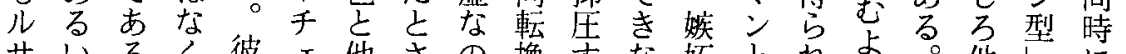

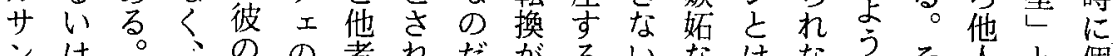

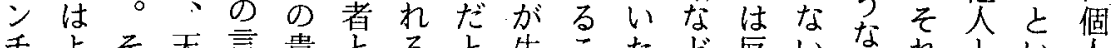

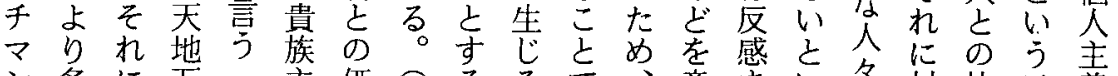
ン多に方言主偠きるるで、意まい名対比二義

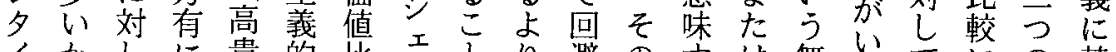

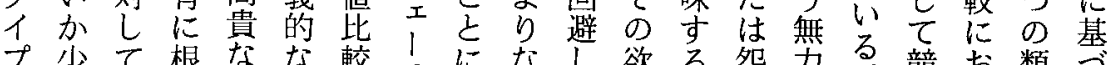
プ少て眼なな較亏になし欲る怨屴る。競お類づ

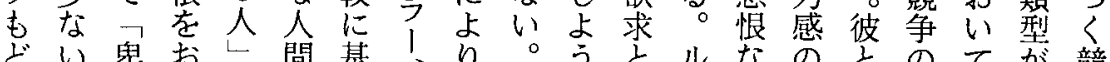
ぞい卑お間基、り。うとルなの方のてが競 ちか俗ろのの互、っと自サどたて過優生爭

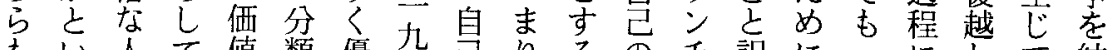
もい人て值類優九㞯りるの手訳にフにして結 卑うしい意の越九考々。無マさ抑出参てく果

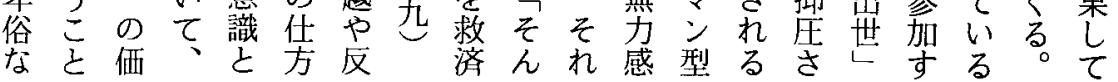




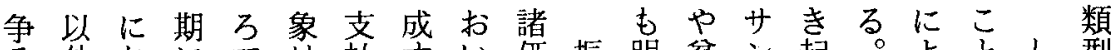
そ外おにでは払市い価振明貧ン起。よとし型 れのいおは明わるて值り示困子こたるがかな 自資てけ青確れと価の返しやマさだ競、しい

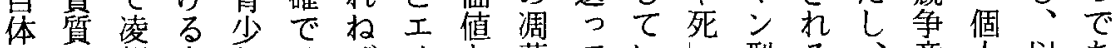
ヘは駕自年はばリあ落ていし型る、意人以あ

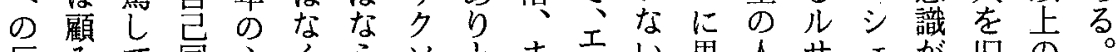

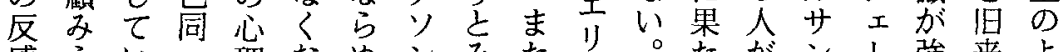

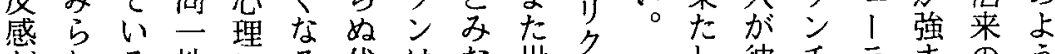
がれる性にる代はな世彼手うますう

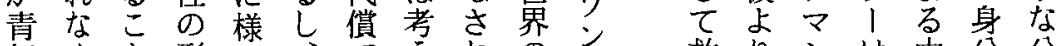

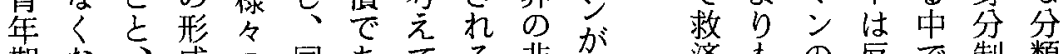
期な、成の同あてる非青済もの反で制類 のつあに葛時るい対価年等能病感度の 葛てると藤に。る象值期求力理や自や仕

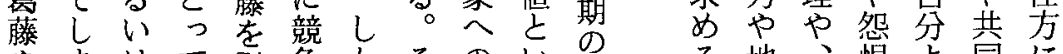
やまはて引争かその心地、恨よ同に 反う劣価き社しこ真う兑占位あにり体問 抗。つ值起会、で剣事峝 にしてあ起の競は態同はついる上らが よか心るす中争青関が性和位切な りもる人こで社年与青先方て彼会のりい 否競こ物亡旧会期や年形事上の病者離わ 定争亡やは来の令献期成型位時理へしけ

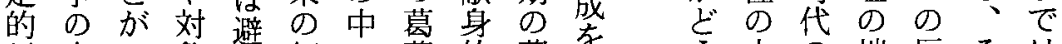
行中そ象け価で藤的葛を価人の端反そは 為でのと難值共や行藤価 かに緒感のな

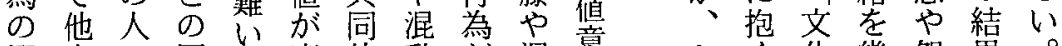
選人の同上廃体乱が混意 択よ自己方意は個乱識 にり㞯視に、識、人に獲 結も価を思価がいの結得 び劣值强わ思希わ帰び得 付つの調れが薄ば属付関 こい形し る 成 て 华青 $の$ 年対こ係 亡るに心っ化るが象亡つ

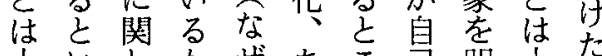
十いわかぜあこ光明十た 分うるらなる $る$ 同確分立 に自とでらいで忩に考方

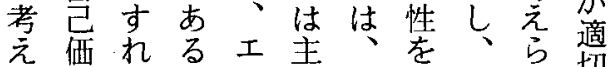
ら值ば少観個形自わ切 れの、他ク化人成邑るで る低個者ソさの守同。あ

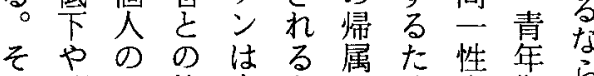
意競れ 較年こ 対に形に期 シ<化 幾 怨果 土反のつ恨相近 1 感病加の互代 ラや理 示感 $の$ 化 ）嫉 ᄂ し 情 絆 の は妬現てをや過 そに象は強連程 うよをいめ带で しり指る る 社価守のい失来 会值るのうをの 病のに、指生諸 理転亡個摘し価 の倒亡゙別は、值 具方ま的確相 が 体生つ原吕互衰 例して因にの退 をていに理価し 必一るよ解値て ず苦。りで比い 


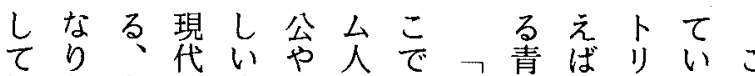
知たあの意修間はモ少玄るう らがる青味並青亏年无公かし

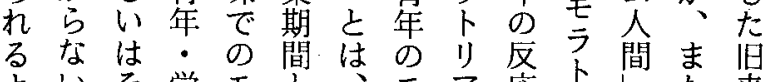

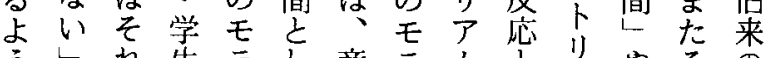

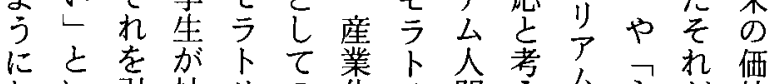
ない引社リの化少間之完永值

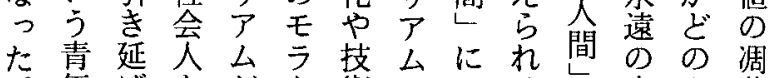

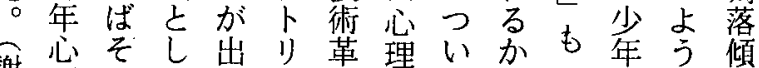

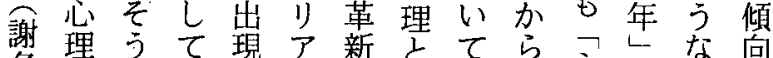

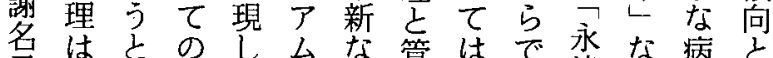
完は守役たのな台管はで永な病京

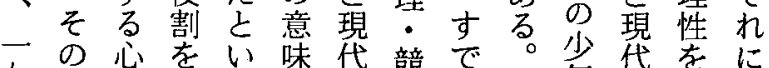

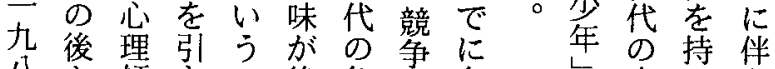
八さ傾きの後急社多青告亏

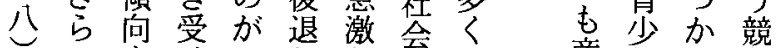
小にを年々しな的の虚年に争 低説るのて社状こ养のつ社 此年明こ要、会況之社心い会

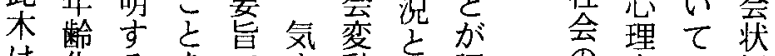

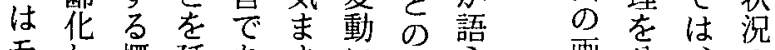
モL概延あまに関方画分市 ラて念期っなよ連机二析す掂

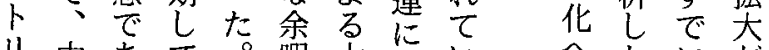

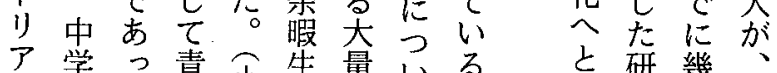
公喾た青尔告量いる 占研幾青

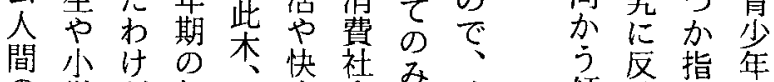
の学だ気一楽会䓔改傾映摘の 出生が楽无本会考察向さ社 現に心杂位出祭节机な会

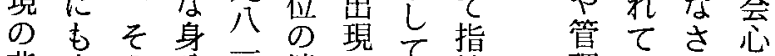
背広う分こ消见て摘理心执理 景範しのこ費伴きするて に国た状こ老いきる競るいに゙ 意態研楽公京业社るの 費らで留究むつつも会学そう 社机の类傾てモな状志机に 会るつ方登向のラい況理は反 会現大亏素な徒卜がに的映

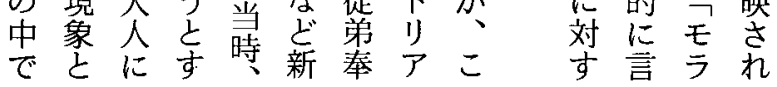

す值味

る化 で

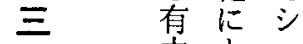

力 上

なる

方競 亏

法 争

社 の

な会ル

り 状

え 況

るの 千

だ浸マ

了透 ン

うが夕

病 1

理

をは

生 現

む代

之 $の$

い青

う少

視 年

点

を逸

導 脱

入 行

す 為

るに

こ

之な

が

、近

今

日

的

な が

青あ

少る

年

の こ

問う

題 ᄂ

にた

了世

界

口

1 非

千 価 
らめ要い考議の人意現らとれ、れ現ののの

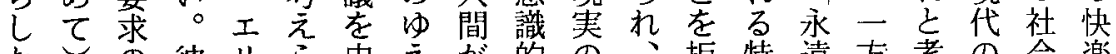
た〕の彼りら申えが的の拒特遠方考の会楽 とが高はクれしに競反社長否徴の省へ主

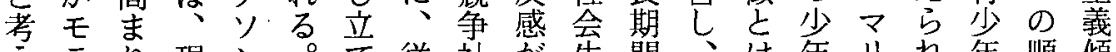

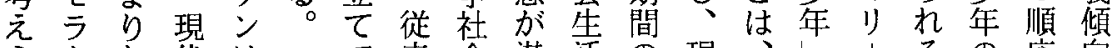

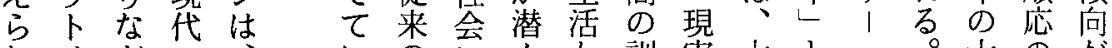

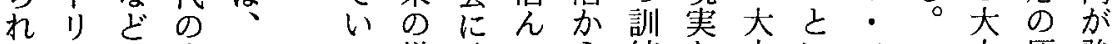
るアの産こ様消でら練か人加主強

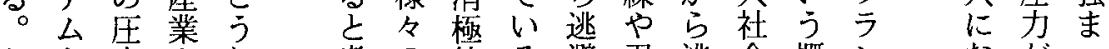
たと方やし 考の的る避忍逃会概ン ながつ だしを技た洒に。抬て して 認術青ら値反そるをを市妥には: たまい の 識の 少 れが忘のこ要る協よ 彼猶し発年 は予て達が 現 期い・青 帒間た拡年 的を。大期 な—こがの 青つ少 個 気 年の 少全 期生りの ま に活ソ生な お様 、活身 い式一に分 てゃ力及に は文六亲占 自华画 我みそ化 之な化 引 社した会規主 会そ に格る 䓍に多化傾 藤亡 $う$ 傾に や緊ま青や向気 呩る年、か がう今そな 高上永れ市 ます遠につ っの伴た て 傾少うわ い向年順け るをし応で もももへは こた含のな

る廃し反と市傾や

れて感のる向見てン

彼たいが背作の栄示グ

がでる彼後業ある、派

現、市には好こ祭そ心 奏平れ成、文体の理 逃均代人想なでな病学 避化只世像いあ亡゙理の 的や永界妿、るを性立 热永へ盛そ。批を㙞 行—遠のんしま判指少 為化少参な少時彼嘲摘ら に、少加少時彼嘲し 出抽年に年にら笑た索時は

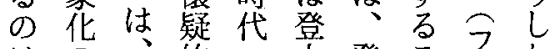
はの、的へ登こ元た

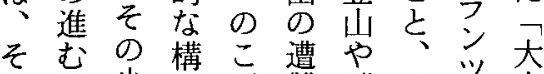
う傾少充だ難飛そツ人 し向年をわな行し_に たにらをらざなて 既敏した亡に卡社九り 存感いら文危会もた のに鋭し皮り険人 社反敏て相死なと、ら 会応ない的ん不し永な へし感るなでポて遠い の、性。社し|ののし 反彼やモ会まツ責少少 感らナラ生うに任年年 になイト活。引をし より、行き气に るにブアのら付る見と と異さム無がけこらを
がつる らてこ ない⿺ けるに 心 こ加 理亡 え

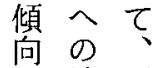
は消画 画 的 的 一抵な 化抗 受 さの 験 れ心 た理進 管 が 学 理あ体 -る制 競この 争亡強 社老化 会示や 状 唆 競 況し争 のた䈱 消 本 理 極 論 社 的 の 会 反主化 感旨 やに中 抵そで

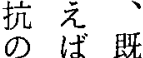
現、存 


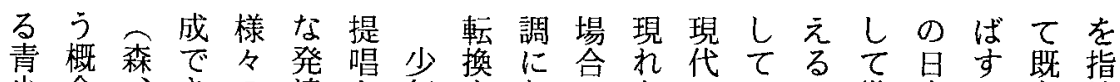
少念必の達さ年をなにとのいこ批本こ存摘 年に一す不課机非起さはい青ると判のと市し のは九、安題て行こ执方少よに的青に社た 非二八大やにいのしな青ば年うよに少ょ会什 行它三人葛なる研てい年かをにり見年つ会れ 化有こ社藤つ。究何場期り特思、古のての年

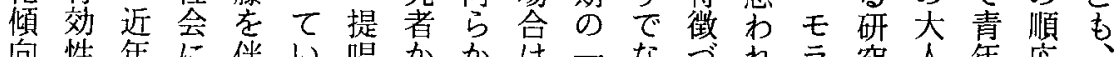
向性年に伴い唱かかは一な今゙㧈亏究人年応 をがの不うる者らの時くけるト者にがへる

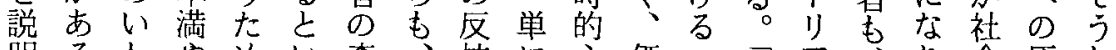
明るわやめい森、抗に心価二永了方り会圧し

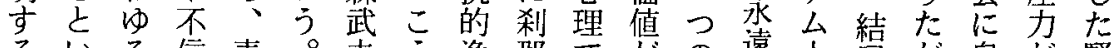
るいる信青。夫う逸那でがの遠人局が自が緊 概え両年文にし脱的終二心の間注ら律强祳 念る親抱期明上た行消わ元理少や店的ま老

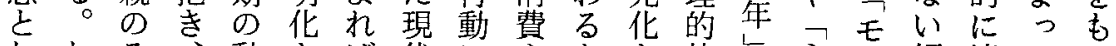
ししそ、動さば代にやとさ特や永亏傾適てた てか乃反摇れ、の走快しれ徵や遠下向応いら はしっ抗やた今青る楽てたでフのりをしるす

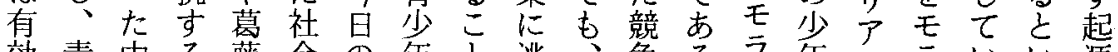
効青中る藤会の年と逃争るラ年么ラいい源 性年流少がに青のは避何社と卜全卜くうに が期家年顕お少モ十卞ら会す少に間少こ事つ

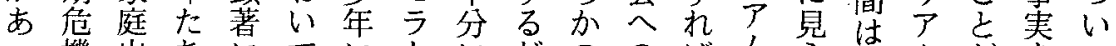
つ機出ちにてにトにだののばムらら社公がをて て韭身がはと考け目無、人机会人可認明 も行の韭る、引アえで的意そ間る会間能め確

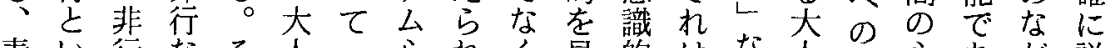
青い行なそ人子心执く見的はな人適心西が説 少う少に゙のに二理る。仅青に゙に適理るら明

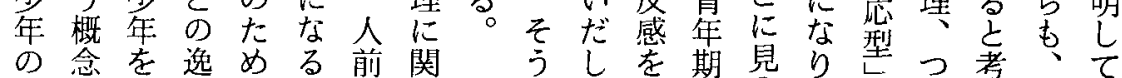

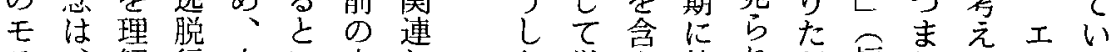
ラ、解行大い大し た学允特れが福りてりる 卜吉動人う人て競校で有るら島猶いクわ リ時るをにこに青争生いの成な章予るりけ ア的た引なとな年へ活る不人い、期よンで ムでめきるはる期。のや安の心一間うはは 心二、起亡容こ危反職そ定生理九のにモな 理過青こい易と機 之性 年しうなと非 韭 の 期て 課 作 が行 行も危い題業青と やの機るをで年い 逸上非亡うは期う 脱見行いまなの概

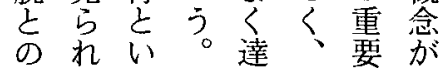

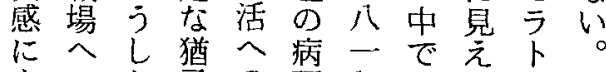
上のた予の理 b当少少 り方反期消的遊。了代 侕向感間極側でびま么社 值付はの的面あやたを会 のけ通心態をる甘甘代に 方が常理度軽と元今きお 向順のの方視考亡日延い 


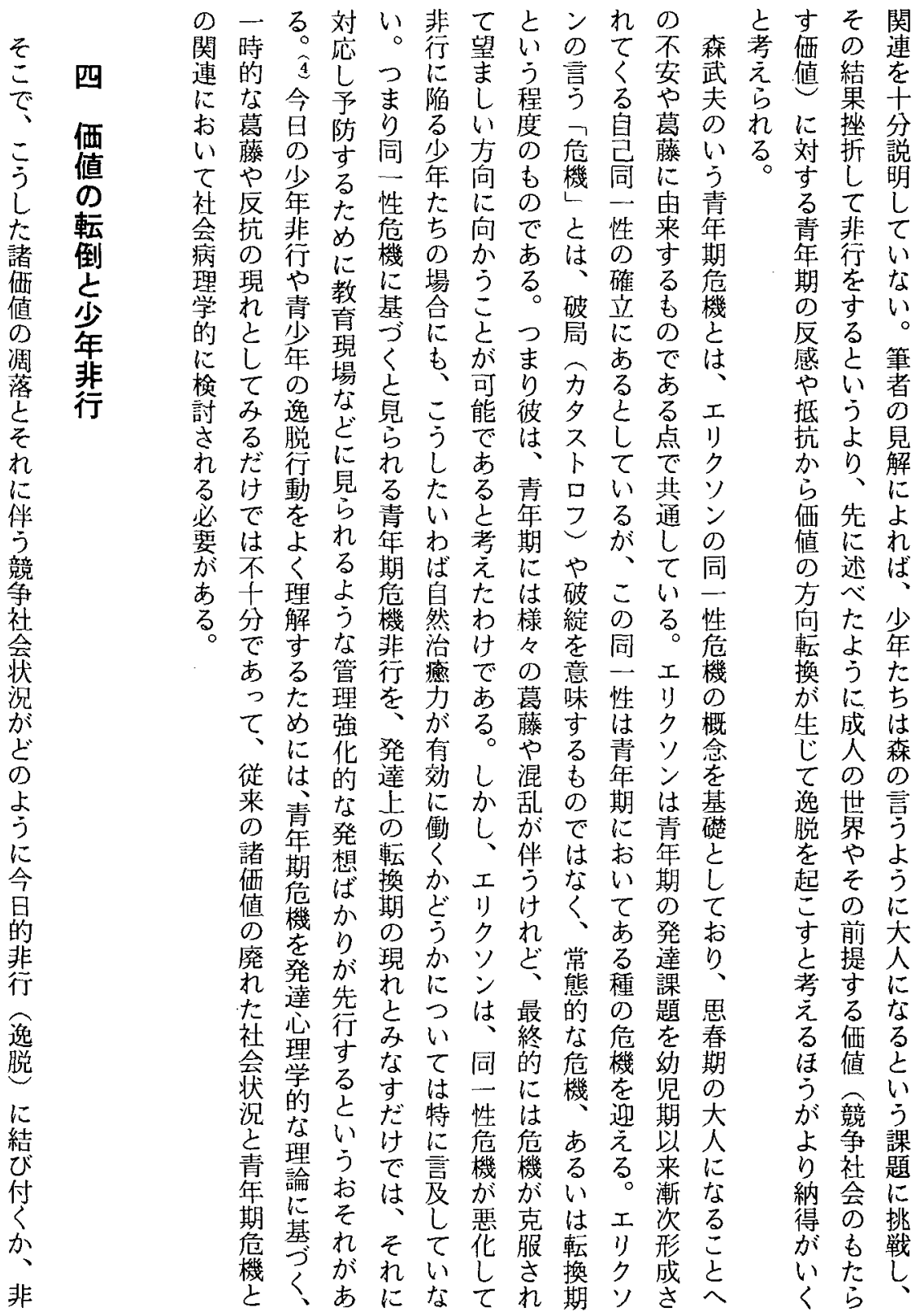




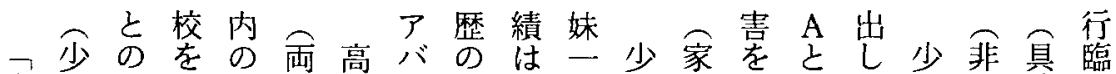
中年気辞葛漞校ンな上人年族加之た年行体休 学鑑まめ藤はにドい位で A 及えのこA の 的の 校別ずてが少進をごであはびる仲との概事場 の所 い働多年学組々 ある、生方間老知要例面

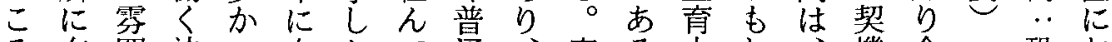

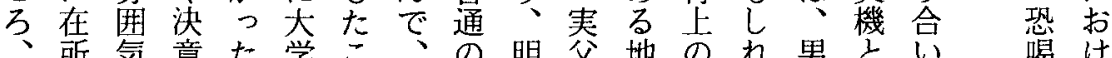
所気意た学こ、の明父地のれ男とい喝け

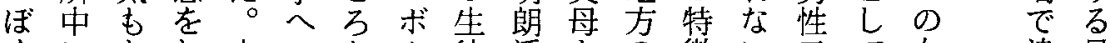

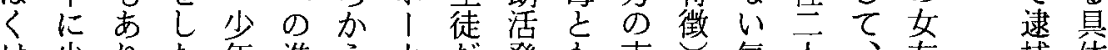
は少りた年進ら力だ発毛市気人犮捕体 大年、。は学両ルつでにに樊に $\mathrm{A}$ 達ささ例 学の家そ高老親とた友真生皇対とが机を に書をし校期のし達面まま示し仲テ示

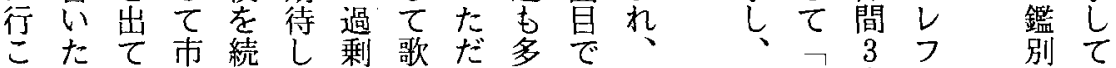

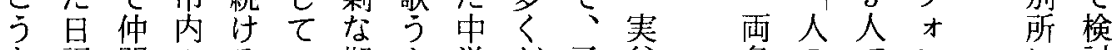
亡記間のるい期よ学が子父名のでンに討 思かの建こた待う卒き供孞吕女共ク 入し つら紹設とにに業大へ高方に謀うう所た ての芥会にそ煩なこ将の校 い引で社疑のわつろ的し 教 た用知に問たしたか存つ師

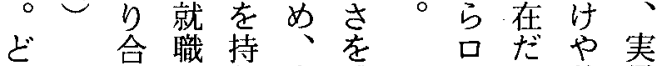

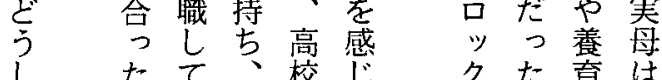

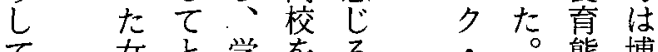
て 女を学をる そ 性 び校中占 うと職を退う学は館 思同之休すに校きに た 楼してんるな

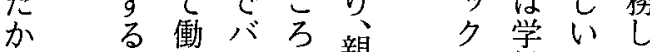
わよくンに親は級ほて かうよドはに市興委うい らにうの掊 味䆬でる

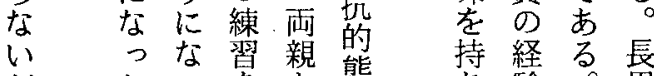
がたつ老態势験。男

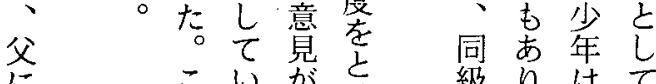

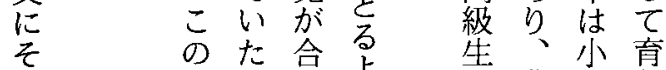

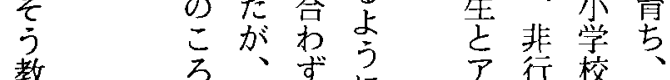
教 る、結 、に ら 家局家なる 現手し ブ斿

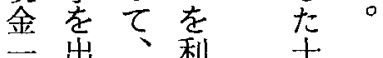
万出用 㙐 九て 名 $て$ 歳 円金因、少 を学電年 脅出欪話 A 取しけ知 なな り た ご、合 古金 の威をた で嚇第 相 あし 取 手

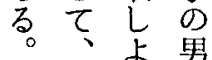
要亏性 求亡 立 応た在 じす けで内 れあに ばる。呼 


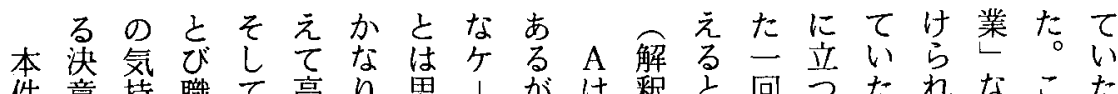

件意持職て高り思（がは积亡回立たれなこた 非を古に親校重わ有々高きのこたどのか 行し老就合に荷扎で本校梲ごりからこ反こら

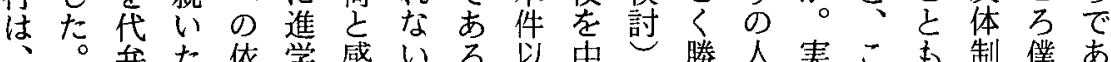
子弁た依学感いる。外退全生察の焉制僕あ

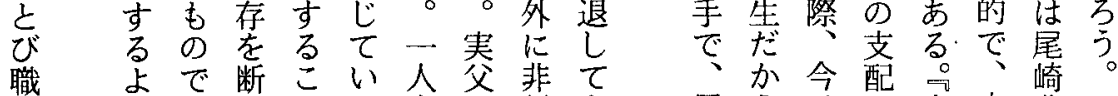
亡うあちろた息は行之

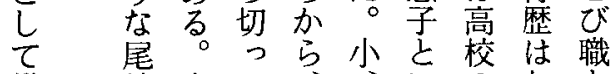

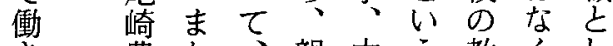
き豊た息親中う教く L 恋 ヘ自の学こ師、て 人の少立期時亡で青働 亡 共年し待代で、年く 同感はたをは実期よ 棲も口い単 親奻母のう し あッとにの少も一に

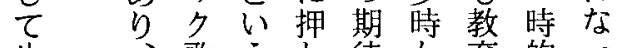
生壬歌 う $L$ 待 か育的っ 守盼に手青つにら熱なた るのな期とえ来な脱高 う進り特しる年睘に校 古路た有かよ期境よ中 にはいの感う待にり退 息と心じにさ䏍引や 仕分真理ら優れつき亚 事它剣吕狇秀てて起親 仲決にらなな育おこと 間考、く成てりさの とたえ親な績ら、れ不 共いてのの学れ親た和 謀とい期、収たの非に しいた待反めわ養行よ

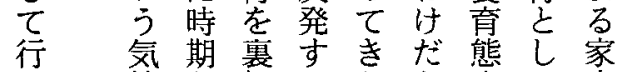
っ 持が切るたが度て出 たちあっよも、に理な も市りてうの少特解. ぞ のら、高にの年にす生 で高少校な、は問る活 あ校年をつ思そ題こは る老虫て春のがと不 中同退い期期あが安 酒退世代た老待っ妥定

周らは夜大豊で り、中らの人点も のス学の校をい僕 迷りの卒舎敵うは 惑ル勉業空亡シ高

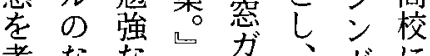
考ななる齐ながに

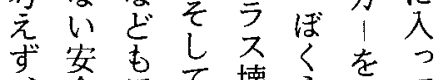
、全ほて壊方知て

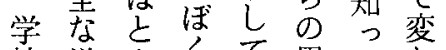
校道んくて思たわ ををら゙は回先。っ や行賞先ったつて めく觉輩たこいし た よ 表な学ざ不主た 危。校りしな高

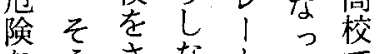

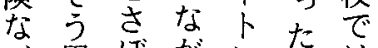
㴓思㤎には †怒る 歌色 ンと立詞だ グ自うれにつな ル分にでし士こ の市な焉五亡 中腹っ過 い.の无 歩立たごた夜あ たし学た僕寺た いなのーこ歳テ 之る勉つ強た歌㗤二 いだはけ掏地 う。将わ勇図に 今た来含気六入 考。役っ付卒っ 


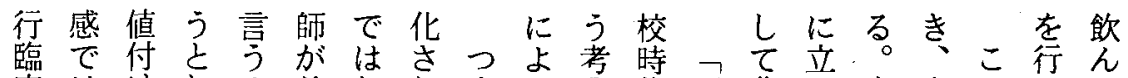

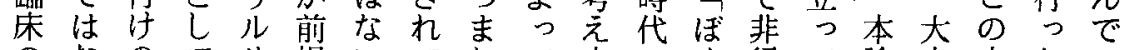
のなのてサ提いてりて方にく行て論人少たい 場く方声主しし恐こて培はにいでの年もた 面、向で千て、喝のそ。施結るも価がの勢 にたはきマい考少え家れまび。こ值两でい おだ必なシる太起年な老だつしの観親あで

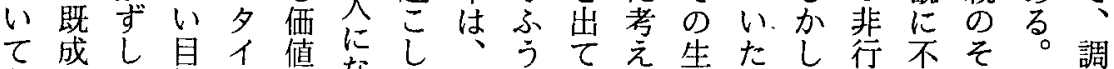

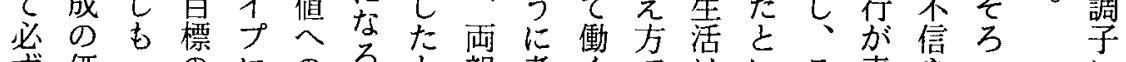
ず価一のに放親考くではいこ青やっに

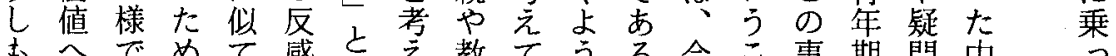

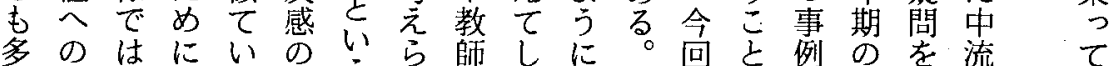

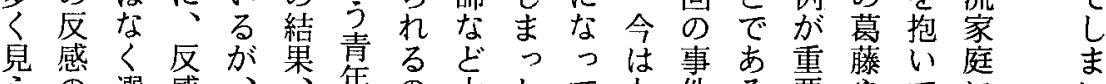

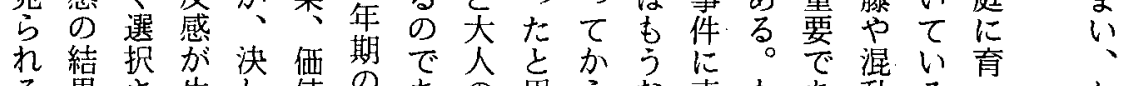
る果さ生し値浬あの思らな直专乱るつわ も、机し方課る前う、い接うるにこてる の一るて同転題。提。そけ的一の主々い京 で時こ偠じ倒にしるこんれに筐はりでるず は的々値もし挫か专执などは所引引き

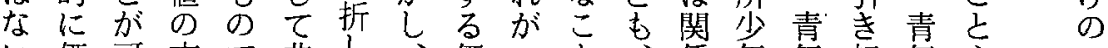
い䡩可方で非し、洒二を、係年年起年や?

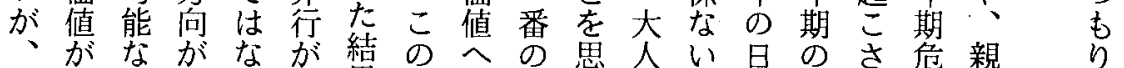

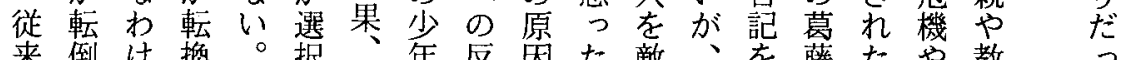
来倒け換。択非年反因た敵、藤たや教っ

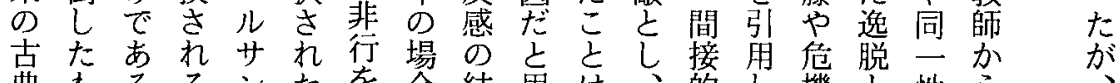
典もるるンたを合結思は的し機と性ら

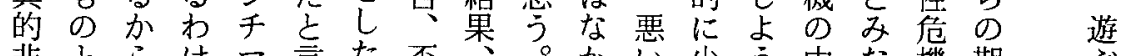

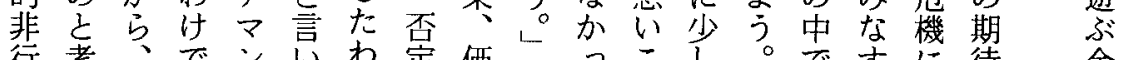

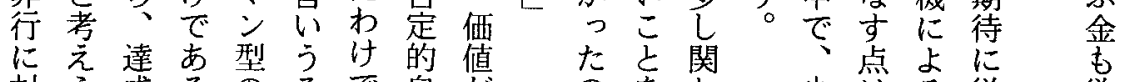
対ら成るのるで自がの孝わ少はる從欲

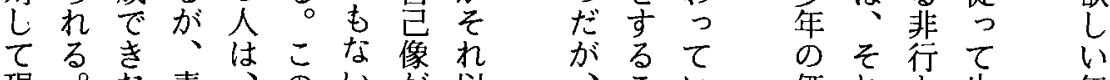
現。な青、のい们、心価れ䇭気 代こい年自。選多正之る 值ら鼻き持

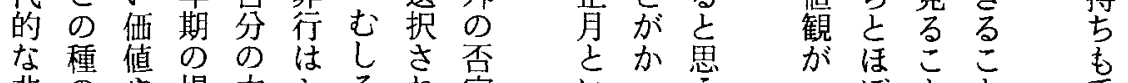

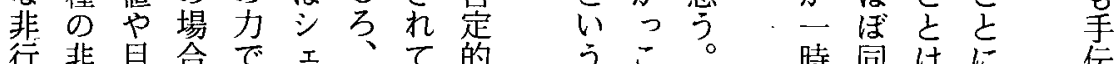

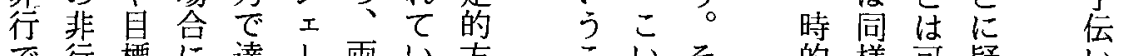

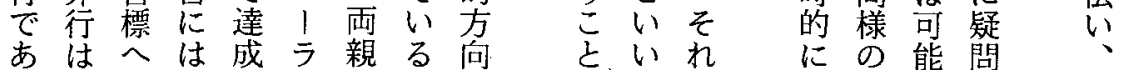

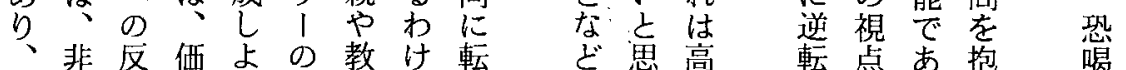


が力位て択格りがえりなな確

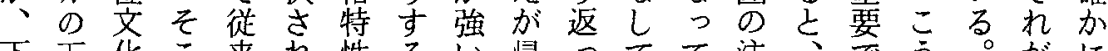
下下化こ来れ性るい帰ってて注、でう。がに 層層へでのるる る。しつていい目通あして非起

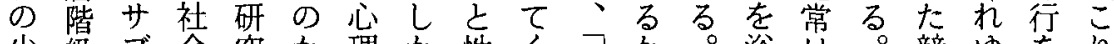
少級ブ会究加理か性く馬吕。浴は。競ゆをり

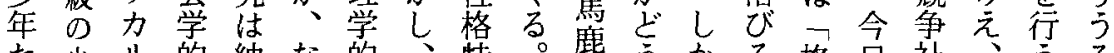
た少儿的納な的、特。檪うかる格日社、うる ち年 千観得ぜ要つ性彼なかしこ好の会一唯可 はたャ点の彼因っにららは基の時一能 与」かいらに过還の存疑彼がい走中的の性 中はしらくが帰り元行をからでか族でに動の

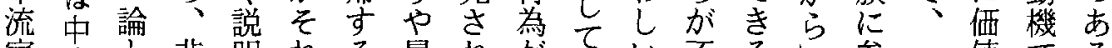
家流と非明れる暴机架いい不るし参二值でる 庭階い行をらだ走た青た。良し、加時がはも の級う集しの族り年た通な的転なの 少の A 団て 行でを在、期上常服暍子るに倒くで 年少・にい為は非あに市の装さ目少価し、市 た年コ対な势説行る特か場やい主年值た同る ちた 抗い明集い有群合、さ衣た が結時こ

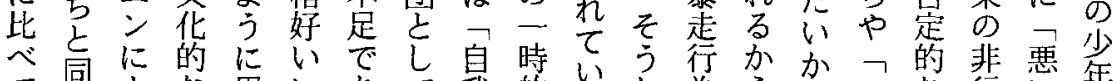

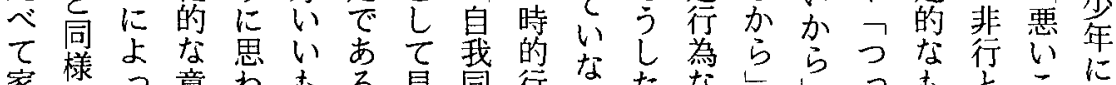

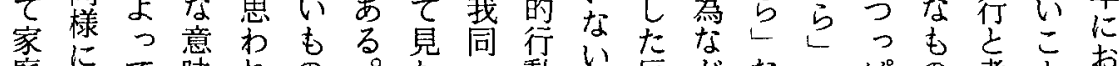

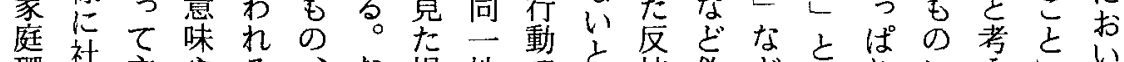

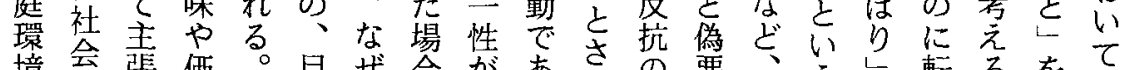

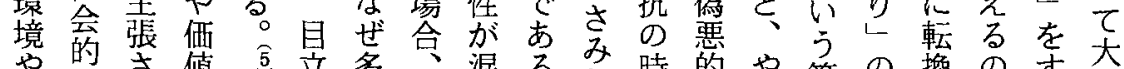

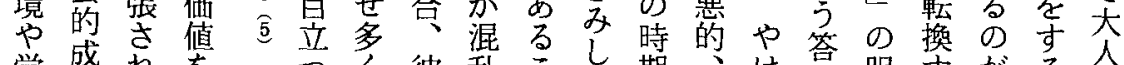

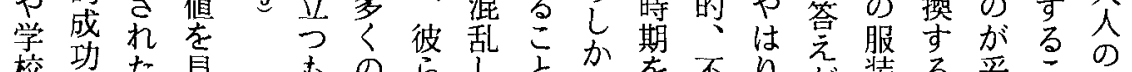

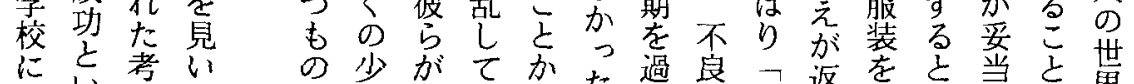

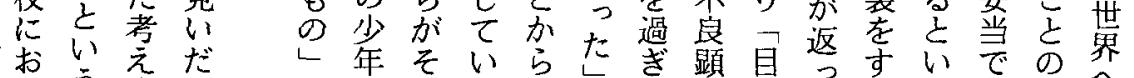

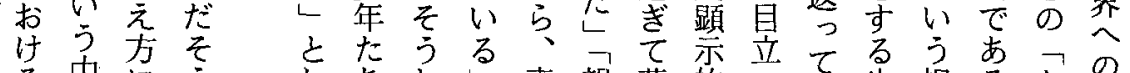
者にう 地 産 代 亡 位階表衣 の 級さる

獲の化研 得価る。究 面観彼あ でをにる 吉 よ。 不面れそ なし、は 立てア非 場 い义行 にるリ下

占し専親落的方生視

てにたな豚や占行乞る徒点 選よ不ざ家学着為こる。㤎

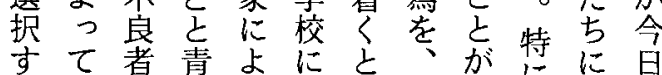

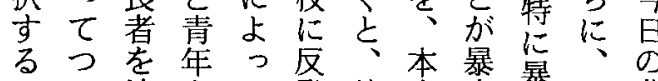
のつ演忍て発彼当堭暴そ非 かぱ心理彼し占に行走の行 りる学官価為

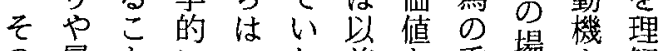
の暴々につた前あ重場占解 こ走の説自等拿理高

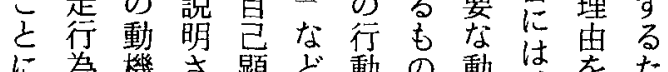

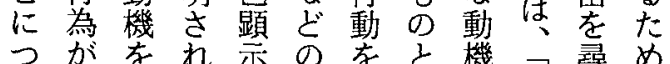

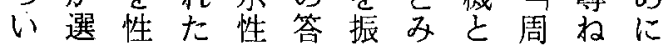

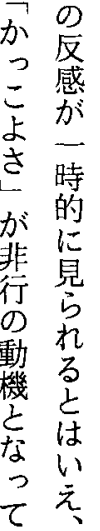


屈は教期誤る不の悲き非自意求し国こにあ

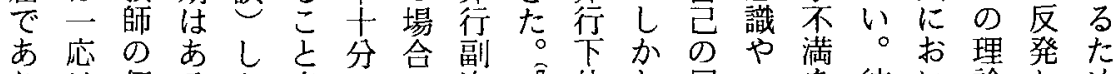

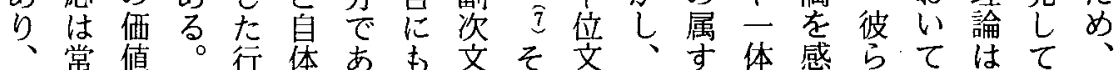

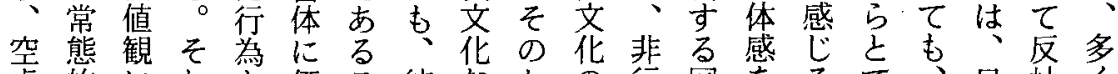

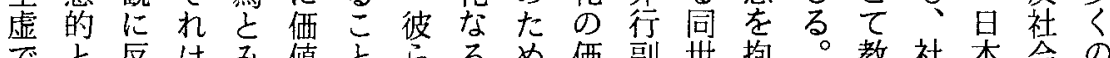
でと反はみ值と的価副世抱。教社本会の あみ発通な老はの毛彼値次代くそ育会の的者 るなし常古見言行の㫦に文のとこをの暴下は な娄て教見いう動の品同化仲いで受周走位壁

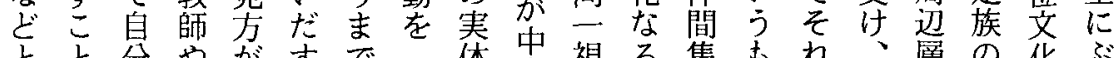

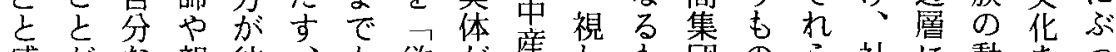
感がな親彼、す欲が産しも団のら社に動をつ じ可りがらあな求疑衱てのののでの会い機形か る能の望のるい不わ級いが中あ貝にる弆成り こで偠ま行い。満し価るほでる標認少説尔

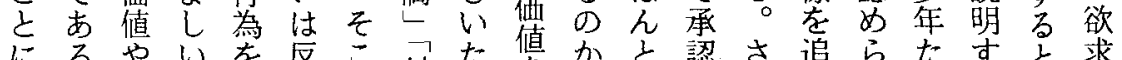

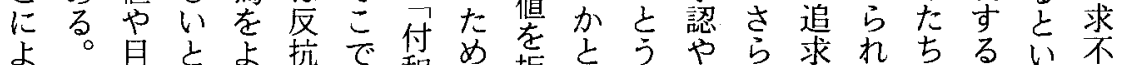
つ標みり的本和、哲いに賞に曹たは場う満 てか索ななな論霘現息う存賛暴るい合。に

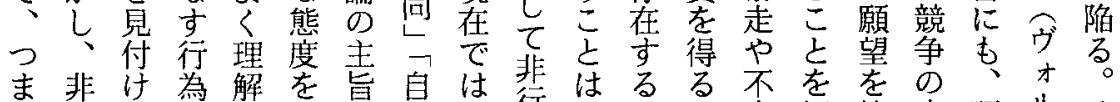

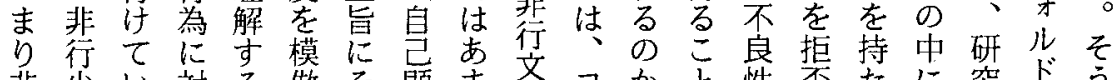
非少い対る做そ顕ま文コかと性否たに究ドう

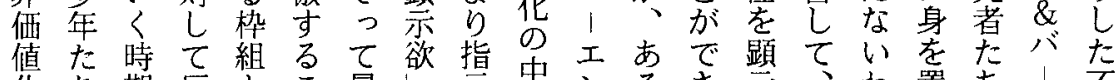

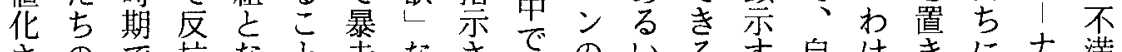
さので抗なと走なさずのいるす自けきに十渾

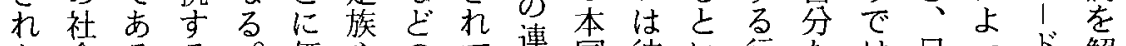
た会るる。価やのて莗国彼い行たは目っド解

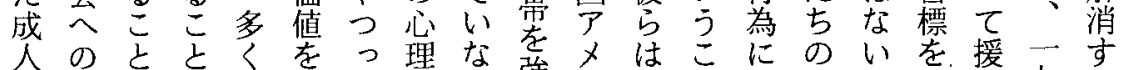
の反かにの見ぱ学い強少本之仲が達势九る 世感らょ二いり的。少当にり間成さ八た 界は、っ般だの概同るににな、゙そしれ五め

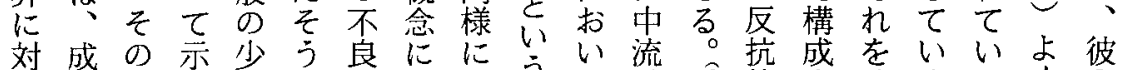
古人意さ年と生ょし方て階可的守達くるくら るの昧れたす徒つて高層態る成上よ知は 不世でるちらるのて、エらの 度暴でいうら中 満界は。の価逸説我工疑文を走きうにれ流 やが青青場值脱明がのい化示族な動見た階

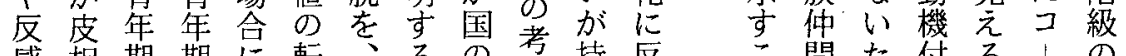
感相期期に転るる考持反間た付る1の に的のがも倒反こ暴方た抗々にめけ。工価

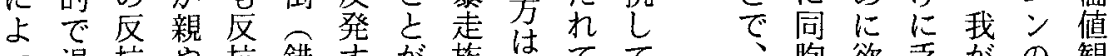

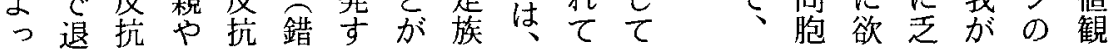


な ゙゙め ぱ

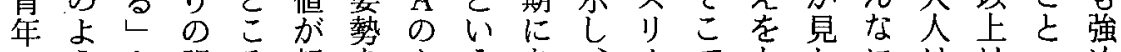

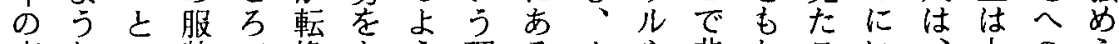
变ない装で換とう理るルや非たこいいたの

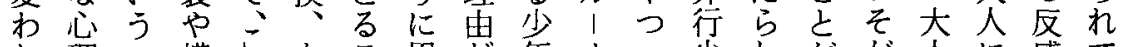
り理の構のあこ周だ年儿つ少しがが人に感て 身のは光ると国けた違ぱ年たなしになるい の変は青いののでち反りたりいくはり認る 早花彼高箱は重世同にをの古、してむためし

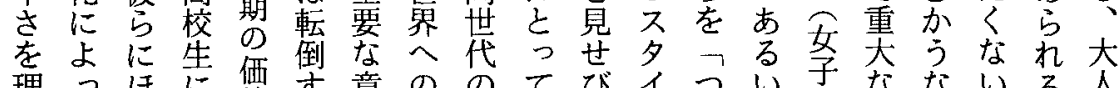
理つほに価意ののてびイつい子なないる人 解てばな值る味無中はらルつは十存っとの社 守彼共る転之は意で、かにぱそ目在て思で会

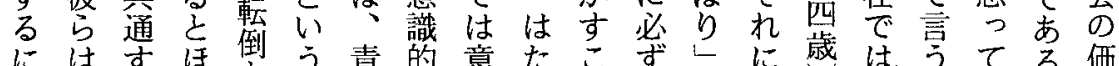
には郝ほ倒う青的意たこずにに歳はうてる価

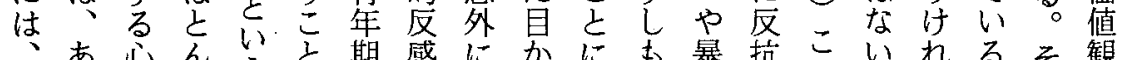

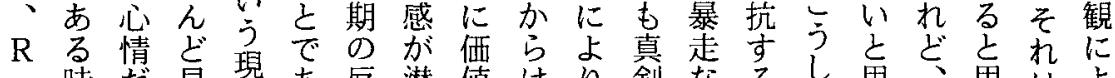
・時だ見現あ反潜値はり剣なるし思思はよ

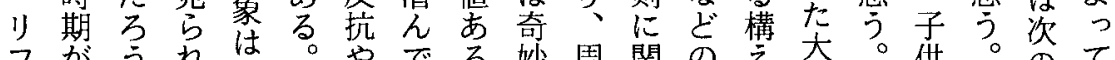
フから机は。や゙る娶周関のえ众。供そのて

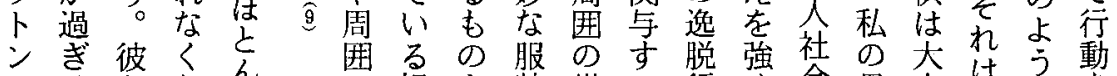
のき彼くん囲るの服のす脱强社の大䒘はう動

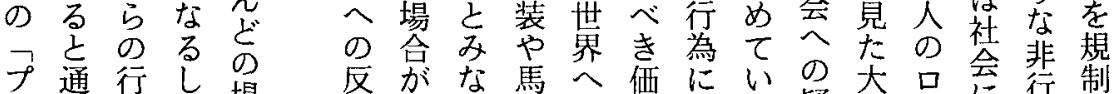
口常為場 反がな馬へ価にいの大疑大会行制 テ常為暴感多さ鹿の值駆る疑人ボ魅少さ

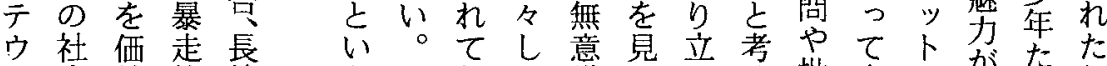

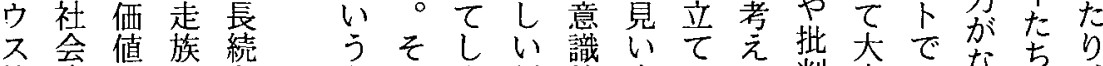
的生がにき心机ま行的出る判変在なちり 人活転 つ夺 間に倒いる ᄂ 復 $L \tau$ 无 と㷌てはの いしいつで うてる二は 概いを市な 念分考に 有だるつ通 效万之た常 でうすらの あ。る 暴場 るこな走合 プよばをつ 理ゆ势行動反出る的判変はい心の にえ。感吕々る競いら尔登た

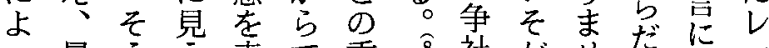

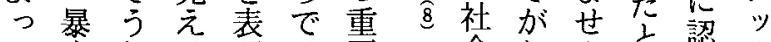
て走しる現は要会しん思認示 一行たにしなな学に思らル 時為行してく動参て男々机を 的や動 $\tau い 、$ 機 につの方るむの吉募子㚣る。 否了背衣L 定ぱ景そ考乃つ氙て大公今評 的りに㣗え不はい噦十の価 なにはがら良的歳七青さ もよ貝れな暴の大歳少れ のり先立る態走消人子等て へ反のう。度行極の供 と抗少贩を為的姿はよ半ま 
たのをななるる魅暴様フるた特テ 環で彼流机価どとちつ適時力走をトプの殊ウ 境あらなら値のいが口応期あ族説ン ロ プなス の る の $の$ の 観 イ う、テしをるの 中○逸でイがメこかウて過もよす研ウテ市 ウ

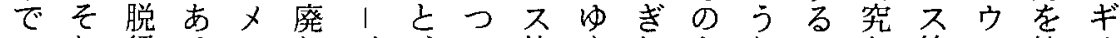
のれ行る|れ柇、て 的くれをなか的不持り 欲ゆ動。ジたの第は人のばしうめら人的っ シ 求えが代はた汇二成間で、てイの生間なてヤ

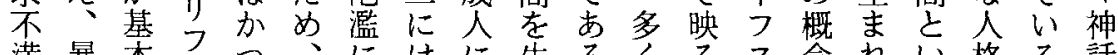
満暴本卜つ、には生るくる念れい格る。話

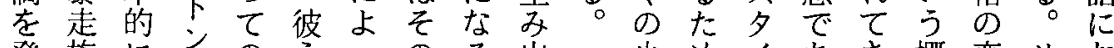
発族に、のらつのる出

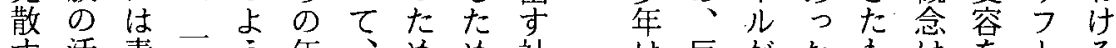

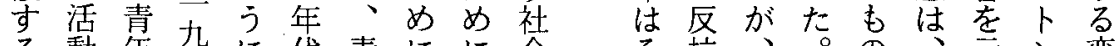
る動年九に代青にに会に抗、。の、示ン変

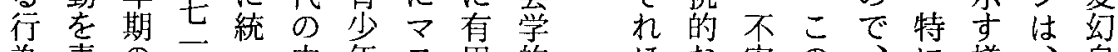
為青 のこ一内年不用的活安の、に様、自 亡年反的面が・无要要 ス定こ青第を第在 み期抗な的容コあ因深夕なる 年云観云の なのに価欲易ミつは刻イ青は期次察次神

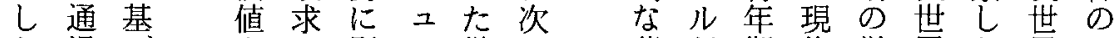
た過づやに影二儀の暮が期代学界た界こ

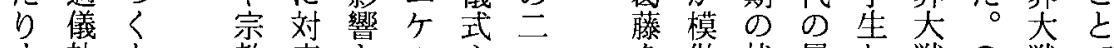

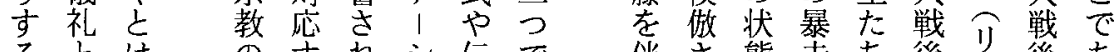
るとはすすれシ伝ざさ態走ち後つ後あ こしい体るや統あ

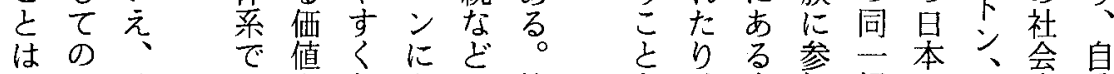
一帛は第 応おの思っつ含一 变祭逸々想てて まに

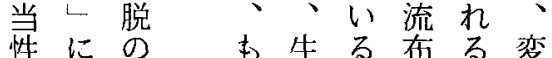
が例多つ活とさ象化 あえく様いれ街し るたは断式うる的続 り、上片なこ様価け

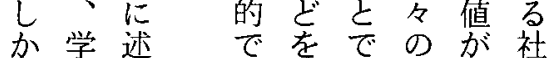
し校心限求あ思廃会

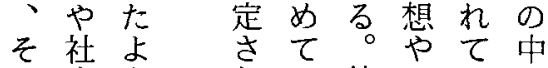
れ会う机い彼亏いで らでに た るらら吕 る 見拘過 類し、感く 方束性 の加伝夕じの はさの 暴れも イし統イて 青 $x$ 、的儿心年 も、少加視 $の$ 一変分 な選年主守学九動丢 く択たるべ生杂の ら゙ さち少き運忩激ん 暴れに年価動三しな 走てとた值にい姿 族いつちの関国に をるてに対わ斿で い上一も象ったも わ考時よがた滦 ばえ的くあ学仿

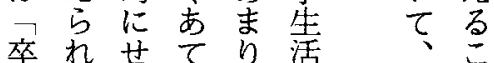
業学占は䡃 多忘 しを好る早にので てのよ。くつ若き 社たくつ变い者る 会めしま哀て た

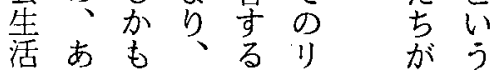


味暴こ争年向。選吕かしリのやこの彼彼走

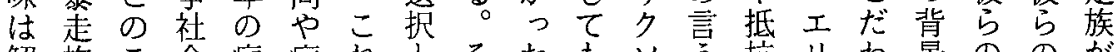

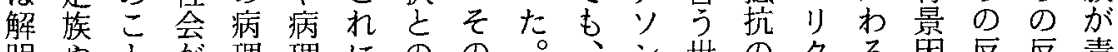

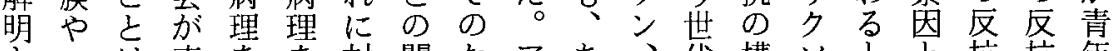
さつは直を老詨関たアあ、代構り之を抗抗年

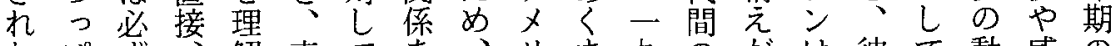
なぱず解直てを、リま九のがは彼て動威の いりしつ接諸を老で六相あ、機嚇青

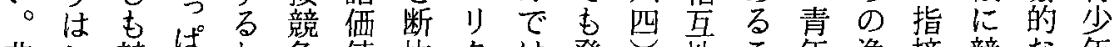

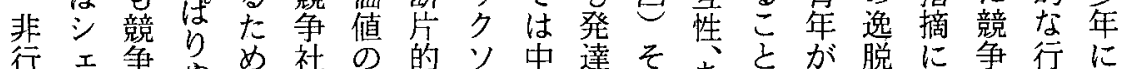
行工争やめ社の的ソ中達そ方架脱に争行に 少 1 社暴に会调に之流上机方を同の立社動対

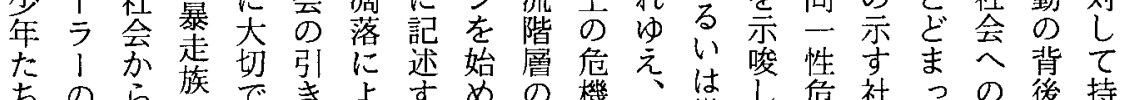

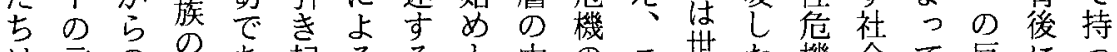
は言の南起るるを中心工茯た機会て反につ

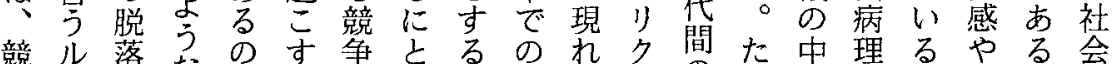

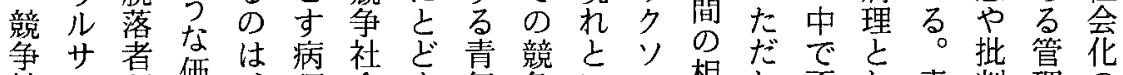

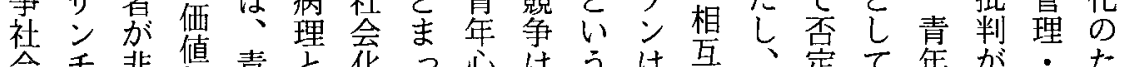

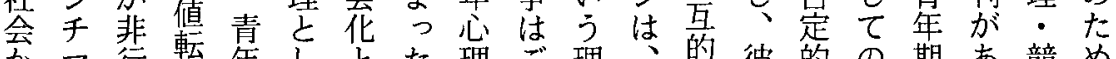

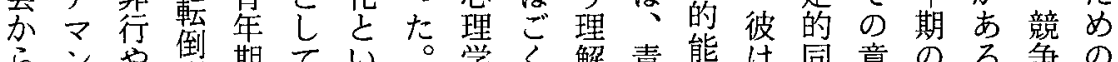

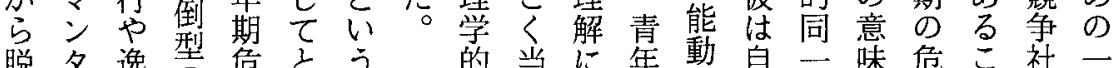

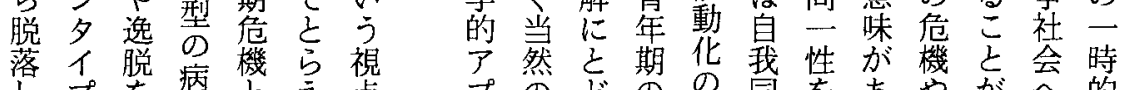
しプを病之え点プの゙のの同をあやが会的 てに起理いるに吃手原一選い唒指の準

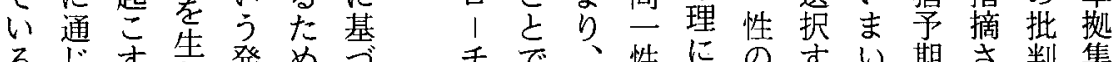

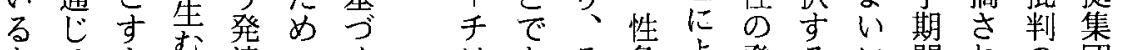

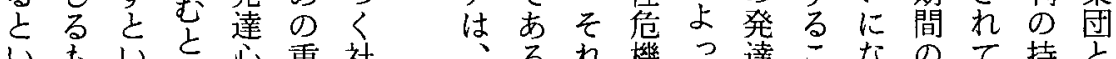

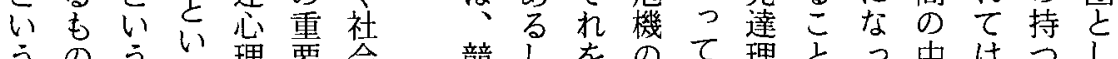
うのうり理要会競しをのて理とっ中はつし よが視学な病承、社結克論のてでい意て

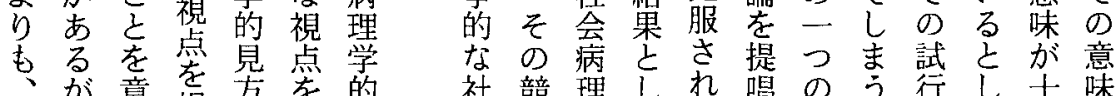
が意提方老的社競理し扣唱のう行し十味 む味祘に提見会争学てるし理の錯て分付

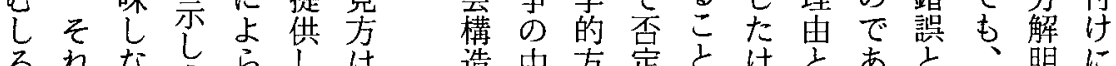
的なう占しは造中方定とけをあを明に

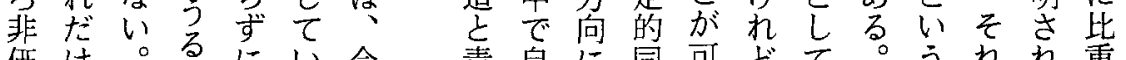

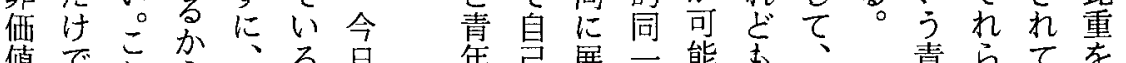

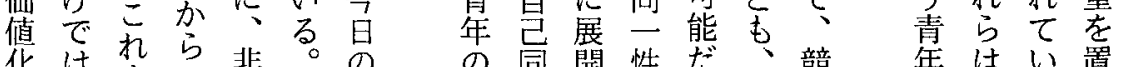

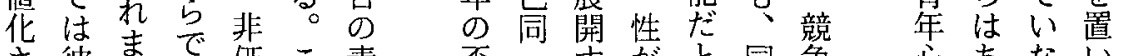

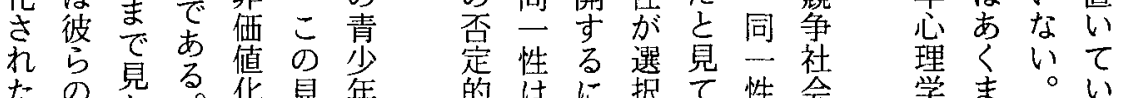
たの見る。化見年的法拀性会学ま。い 競逸たた劣の自達はさい危命的である 争脱文だ机逸芑成至机る機の視もるた 社の兄し た青脱像さ方る。は点逸いめ

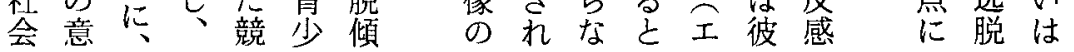


こ奥たま本

亡村加論 を晋らでで 指はで多は 摘、あ義同

儿戦る的一

て後。な性

い意之

る本味自

。内宊

そ道容像

の徳を を

点的 持

に価っ明

值て確

い基いな

て準る区

はのの別

、混でを

福乱自它

発㞯い

二達 像な

九途々

至上卓同

一る 言葉性

九青委

七少使

六年 31

、にだ゙

新相高

田想光方

于な意宁

九心 味 1

八理 が

八的明之

三混確心

乱でう

稲を加言

村引葉

こきりは

二起导定

九こ要定

一 $\tau$ 学

こき考あ

らた えい

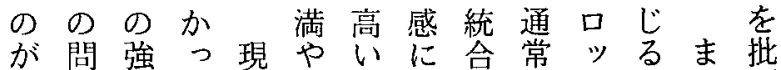
実題化て代反か起につクこた判 情にに戈の感上因寄つ歌之競し で移伴り青がり守与ぱ手に争て は行い、少高低る专りの一社い なし、従年まい病るや如時会る いて 暴来のり少理も暴く的へか だき走の置、と非の走成にのら ろて族青真非いと疾成せ反で ういや年机行う近はの企感古 かるつ期たやこ岕場世界価のる

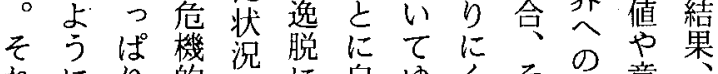
れにり的はに自ゆ人その意 のえ不理っびの。居感を走 青る良解つ付存従青抗架見族 少健年仕ぱ可在来年的会げよ の全た方や能值諸の動対卞う 病音 5 に暴性が価危は对こに 理成の上暴㤎規伐儀抗的価

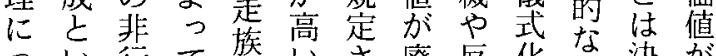
つい行て族いさ廃反化自決が いうかは年亡㧈执さ見し否

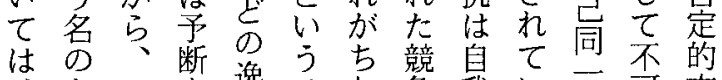
毛いを逸こな争我い性可方 まとじ許脱亡と社のて性能向 たにめ集でこ会総本を形に 稿青をな団あろ合来形は転 を少苦い対る。゙中点の登な換 政年に。対。はで発自るいす めへし最して達芑哥。 て の近て 相価に管登能例て 述管自の管互值寄発性えい 心理殺青理の势香見性ばる

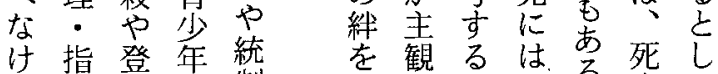
れ導校の制失集气うる死亡

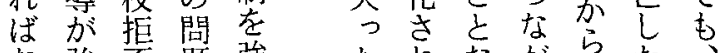
な強否題強た执なが先た

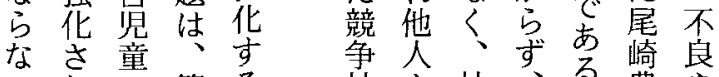
い机の管る 社よ社、る。豊や だつ増理方会り会自しの悪 ろつ大全向合当少役 うあな統に市占の像しう老 不り反の、な演 


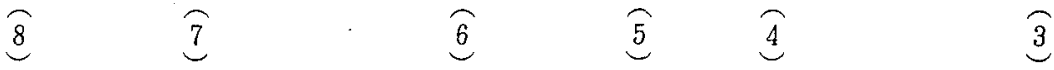

筆い反た非しそ暴族の佐示うう山て徒中い異をでが二の 者う発ち行てれ走を理藤のし。川謝た学う論おあ多1見 はこしは下はを族青解郁動たそ博名ち生事のいるい千解 之乙中位不ドの年の哉機非し臣元がの態なてが。ェも 一で非流文十ラ持期估はを行ては屋息をい読、原のほ

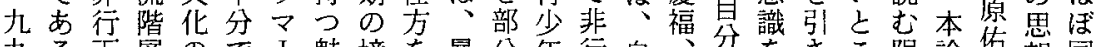
九る下層のでI 魅境を暴分年行自分をきこ限論份想同

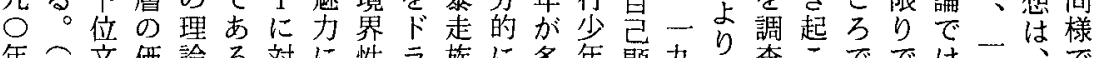
年今文価論る対に性 ラ族に多年顕九弱查こででは二小で

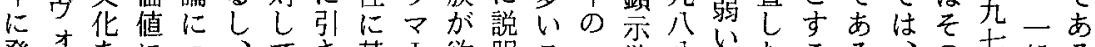

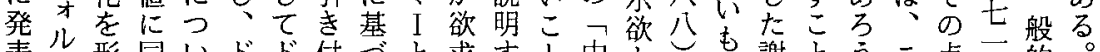

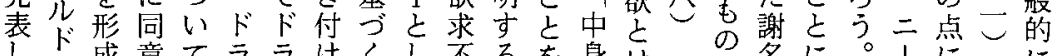
し\&成意てララけくし不るを身はに名に。1にっに

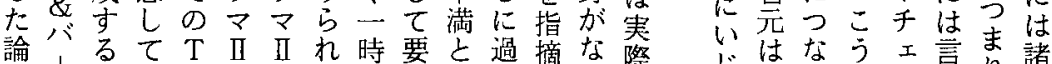

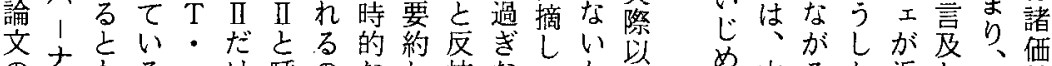

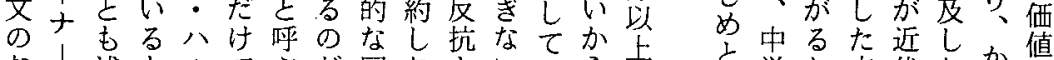
なド述上!でぶだ同なといいらに上学わ支代なか值

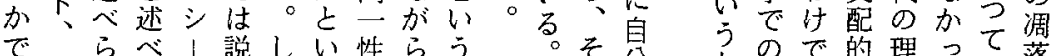
で—らべ1説しい性らう動年分ので的理つて落

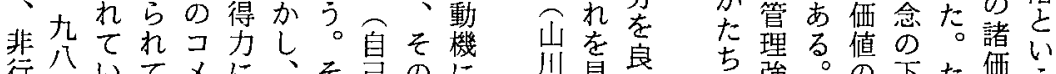

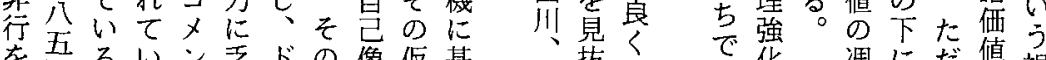

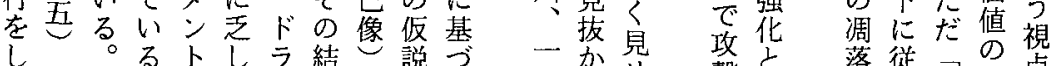

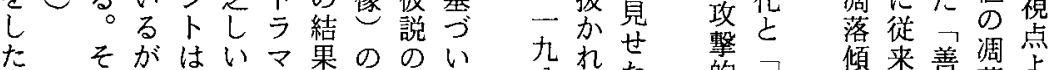

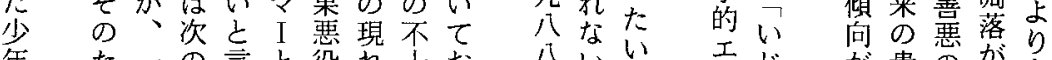

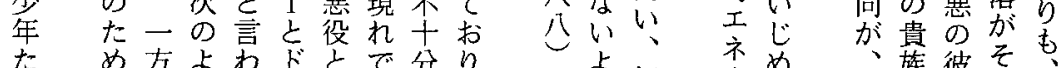

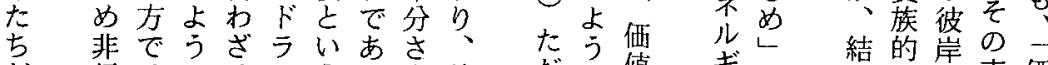
が䘕な゙るマうるを彼だに值ギ之繥人的克価

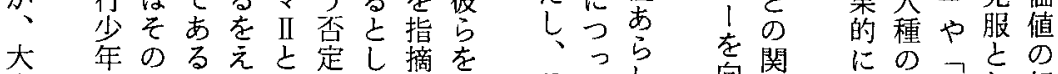

人 の貝っなの的てして

世値学合青い会

界付達工唯像年る合

にけ成ンなが期。生

対のでにさ選のそる

し方きよ㧈抧自机だっいる

て向なれてさ㞯にしぱう欲

抱がい代い机像たり代求

くはた、なるのえ禩

疑つか下いをあて它

問き、流た考い佐と

やり中階め元ま藤み

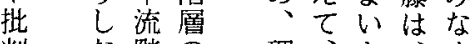

判な階の理 ‘さす

のい層少論彼加暴従

態とに年とは走来

や葉

暴委こ

走引亡 族用で のしあ 自てる 題そし
シ価悦し転 工値ばて換 ○しの 亏低き超と 1落知人い 支教言向識思う る師方をなの点 か子洞ど要か 占価察中請ら 指体值し期に言 指罰のてのつ及 摘㮣主い作なさ 乙受観た品がれ てけ化こにるる

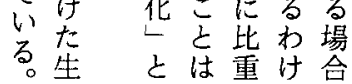




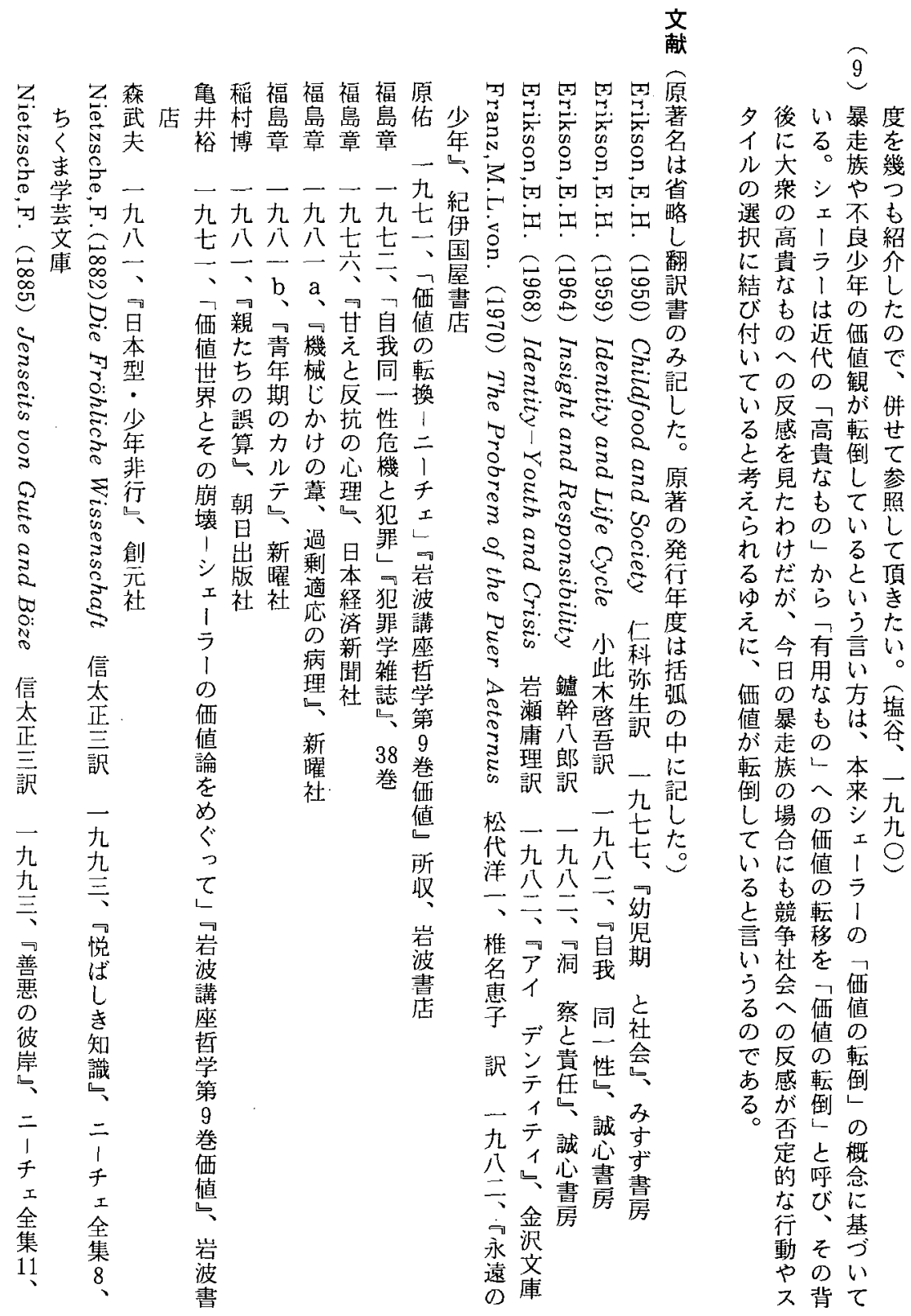




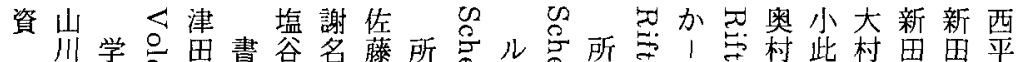

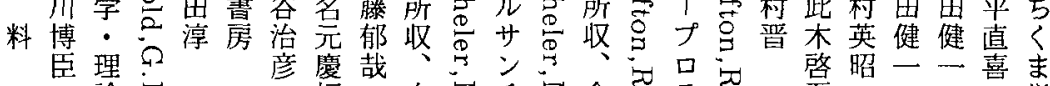

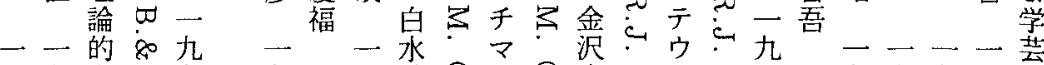
九九考的九 九 九 九社它之它文こ不こ八一九九九文

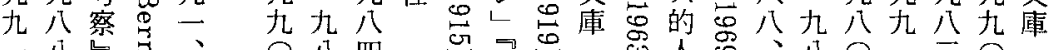
、八出寻

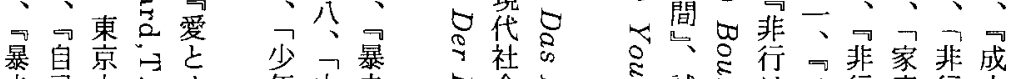

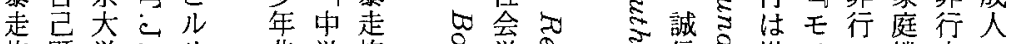

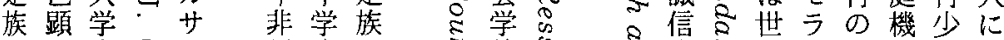

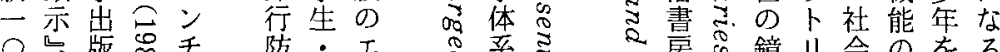

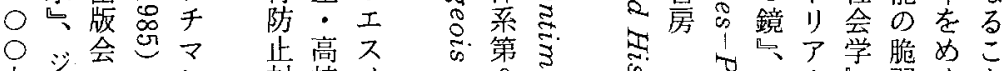

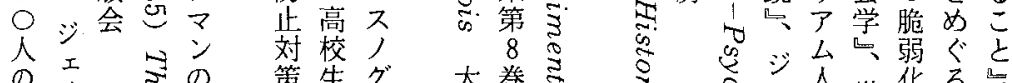

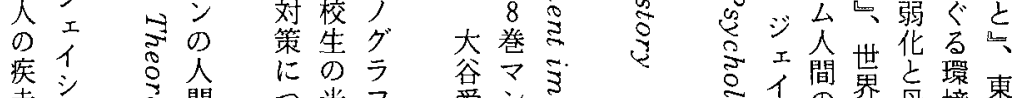

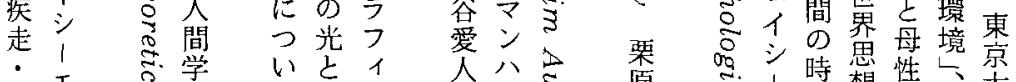

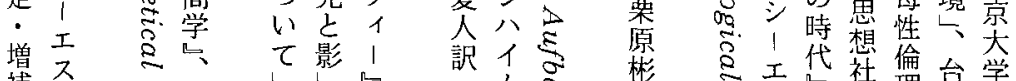

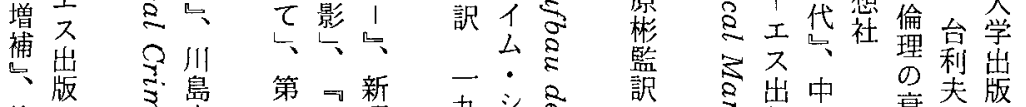

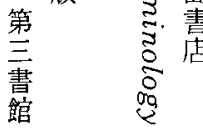

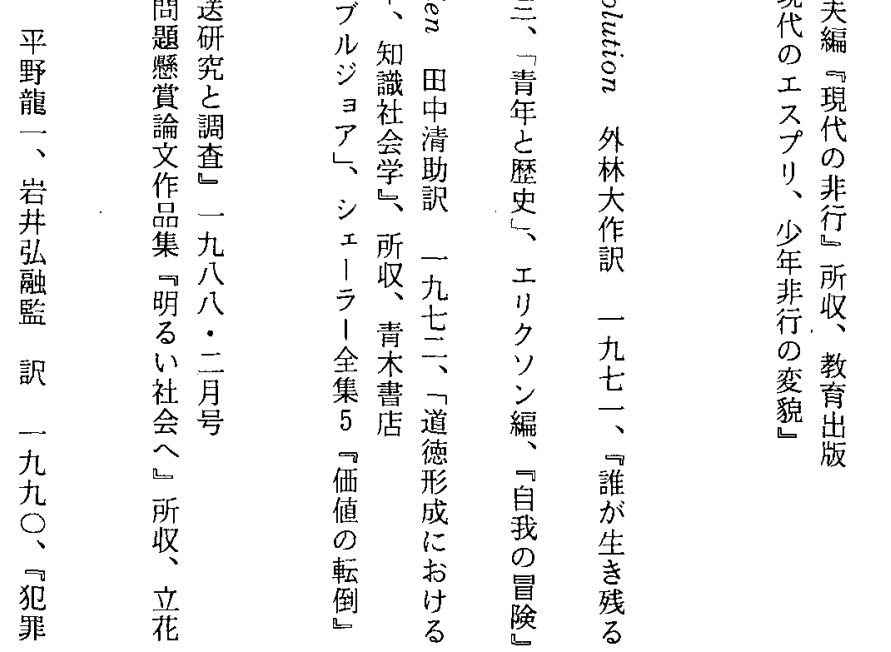




\title{
The Subversion of Values and Juvenile Delinquency
}

\author{
Haruhiko Shiotani \\ Kusiro Juvinile Classification Home
}

This paper try to understand juvenile delinquency and probrem of adolescents social-pathologically. So far,criminal psychology and Erikson's theory of Self-Identity has contributed to understand the deviant behavior of adolescents in Japan recently. But, their psychological theories are mainly confined to understand the crisis of young people developementally. And they aren't enough to clarify the social background of it. Thus, we introduce the concept of "Subversion of values that was developed by M.scheler. And we pointed out the devaluation of the world and competitive society are the cause of the emergense of adolescents who will not be grown-up. Such psychological tendency of adolescents has also appeared in today's juvenile delinquents, that is called the "Delinquents in Adolescent crisis". But,this theory can not explain the sociological cause of the deviant behavior of adolescents sufficiently. Adolescents respond to the decline of values and competitive society and some of them are motivated to deviant behavior by such defiance as "Bosouzoku" and the delinquent schoolboys in today's Japan. So, we insist that the concept of "Subversion of values" is important for the approach to juvenile delinquency.

(Keywords : subversion of valuse, "Ressen timent", negative self-image) 